\title{
Current status of traumatic brain injury research in Malaysia: A systematic review
}

\author{
Alina Arulsamy* and Mohd. Farooq Shaikh
}

Neuropharmacology Research Strength, Jeffrey Cheah School of Medicine and Health Sciences, Monash University Malaysia, Bandar Sunway 47500, Selangor, Malaysia.

* Corresponding author: alina.arulsamy@monash.edu; Tel.: +6010-279-0755

Received: 26 June 2020; Accepted: 24 September 2020; Published: 5 October 2020

Edited by: Kheng-Seang Lim (University of Malaya, Malaysia)

Reviewed by: Norlisah binti Mohd Ramli (University of Malaya, Malaysia); Vairavan Narayanan (University of Malaya, Malaysia); Anonymous (Malaysia)

https://doi.org/10.31117/neuroscirn.v3i4.52

\begin{abstract}
Traumatic brain injury (TBI) is a major cause of death and disability worldwide. In 2009, the National Trauma Database Malaysia reported that nearly $80 \%$ of traumas in the population were caused by road traffic accidents, with $64 \%$ of these cases related to TBI. Despite these concerning reports, TBI reporting systems and research are still limited in Malaysia. Thus, this systematic review aimed to identify and evaluate the available literature on TBI in Malaysia in order to uncover the status of TBI research in Malaysia. A comprehensive literature search was performed on four databases (PubMed, Embase, Medline and Scopus) regarding TBI in Malaysia. Critical evaluation of 60 relevant articles after application of inclusion and exclusion criteria have indicated that TBI research in Malaysia may have significant limitations in representing the actual TBI population and was lacking in basic TBI research. Thus, there is a dire need for government and private institutions to provide support for the advancement of TBI reporting and the progression of basic, clinical and translation TBI research in Malaysia. This will create a deeper understanding of TBI, contributing to global TBI knowledge, and advancing the development of efficient interventions for Malaysians with its population heterogeneity taken into consideration.
\end{abstract}

Keywords: population studies; long-term outcomes; basic research; ethnicity

C2020 by Arulsamy \& Shaikh for use and distribution in accord with the Creative Commons Attribution (CC BY-NC 4.0) license (https://creativecommons.org/licenses/by-nc/4.0/), which permits unrestricted non-commercial use, distribution, and reproduction in any medium, provided the original author and source are credited.

\subsection{INTRODUCTION}

Traumatic brain injury (TBI) is not just a single event, but a disorder with a high mortality and morbidity rate worldwide (Hyder et al., 2007; Rubiano et al., 2015). In 2018, a paper in the Journal of Neurosurgery referred TBI as a 'silent epidemic', and their model estimated that annually around 64 to 74 million new TBI cases were reported worldwide (Dewan et al., 2018). Interestingly, they showed that the major risk factor for TBI was road traffic accidents, which were greatest in Southeast Asian and African countries ( $56 \%$ of global TBI cases, respectively) (Dewan et al., 2018). Although global mortality and morbidity rates are yet to be accurately determined, the Centre for Disease Control and Prevention (CDC) reported that an average of 155 people in the USA dies daily from TBI (Centers for Disease Control and Prevention, 2019).

Despite these alarming figures, the multidimensional cascades of secondary injury pathologies of TBI, which include but are not limited to neuroinflammation, mitochondrial dysfunction, and glutamate 
excitotoxicity, still lack sufficient understanding, thus leading to ineffective treatment and prevention strategies (Pavlova et al., 2018). These secondary injury mechanisms of $\mathrm{TBI}$ may often persist for months to years later and are often associated with the later development of a range of neurological disorders such as Alzheimer's disease (Fleminger et al., 2003; Nemetz et al., 1999), Parkinson's disease (Gardner et al., 2015), Amyotrophic Lateral Sclerosis (Chen et al., 2007) and even neuropsychological disorders (Fann et al., 2009). Thus, TBI may not only affect the quality of people's lives, but it also may create a substantial economic burden as well (Coronado et al., 2012), especially when accounting the cost associated with their long-term outcomes. Middle-income countries like Malaysia are especially more prone to these burdens, given the high incidence rate of traffic accidents coupled with the possibility of inadequate trauma care facilities especially in district general hospitals (Sethi et al., 2002), leading to poorer outcomes post TBI (MaHTAS, 2015).

In Malaysia, TBI was deemed as one of the top three common admissions reported in intensive care units (Rai et al., 2017), which was not surprising given the number of road traffic accidents reported annually. Nevertheless, actual nationwide incidence rate and statistics on TBI remain underreported, especially when accounting for non-road accident TBI cases, such as falls or abuse. The National Trauma Database Malaysia (NTrD) governed by the Ministry of Health, took the initiative to report $\mathrm{TBI}$ cases in Malaysia annually. However, only 4 reports, thus far, have been published, with the last report only updated in the year 2011. Furthermore, these reports only included major trauma cases, that were identified by 8 participating hospitals in Malaysia, and consisted of various types of traumas, instead of being TBI specific. Underreporting of the actual number of trauma cases was even recognized as a limitation by the report, but a solution to this problem was not discussed. In brief, the 2011 report showed that in the year 2009, nearly $80 \%$ of trauma cases in Malaysia were due to road traffic accidents, which mainly affected many younger $(15-24,34 \%)$ males $(87 \%)$ (Jamaluddin et al., 2011). These figures are likely still valid to this day. Although the survival rate may be higher than the death rate among Malaysian trauma patients (Jamaluddin et al., 2011), follow up studies have yet to be effectively established or recorded, to determine the long-term outcomes post-TBI, despite the recovery in these patients.
Similar to the reports on TBI statistics, TBI research in Malaysia is still very scarce. Given the vast diversity in culture, ethnicity and genetic heritage among a multiracial country like Malaysia, this knowledge gap on the prevalence of TBI in Malaysia, and research on postinjury secondary outcomes and interventions that are catered for Malaysian citizens, requires urgent attention. Therefore, this systematic review aimed to elucidate and critically evaluate the current status of TBI research in Malaysia, in hopes to create and increase awareness for TBI research in Malaysia, as well as identify areas of improvement in Malaysian TBI research for the benefit of its people.

\subsection{METHODOLOGY}

\subsection{Literature Search}

A systematic literature search was conducted to identify and extract all currently available literature related to traumatic brain injury in Malaysia. The search was limited to the data available until $10^{\text {th }}$ June 2020 . The search terms ["traumatic brain injury" OR "TBI" OR "concussion"] AND ["Malaysia"] were used in four databases: PubMed, EMBASE, Medline, and Scopus. The Boolean operator "AND" was used to link both the search terms together on all databases. Embase Subject Heading (Emtree) terms were used for searches on EMBASE with '/exp' used to explore the terms and capture all related articles to the terms. Title, abstract and keyword search of the terms or similar relevant variations of them were used on Pubmed, Medline and Scopus, with ALL search performed for the term 'Malaysia' in order also to capture articles with institutional affiliations in Malaysia. Articles were first screened through their titles and abstracts, before proceeding with the full-text screening of relevant articles.

\subsection{Study Selection and Inclusion Criteria}

The following inclusion criteria were applied during study selection: 1) peer-reviewed original research articles that investigate traumatic brain injury within Malaysia only, 2) articles with full-text availability. The following exclusion criteria were applied as well: 1) articles labelled as symposiums, editorials, book chapters, conference papers, case reports, reviews and systematic reviews, 2) articles which were not in the English language, 3) duplicated articles, 4) articles that did not focus its investigation on traumatic brain injury, and 5) articles that did not have an association with Malaysia in terms of research or a Malaysian institutional affiliation. The selection of studies was conducted as per the Preferred Reporting Items for 
Systematic Reviews and Meta-Analysis (PRISMA) guidelines (Moher et al., 2015).

\subsection{Quality Appraisal}

The quality of the selected articles included in this systematic review was assessed using different tools. The prospective and retrospective studies were appraised using the Quality Assessment Tool for Quantitative Studies by The Effective Public Health Practice Project (EPHPP) (Project, 1998) (Table S1). The cross-sectional studies were evaluated using the recently introduced but validated Appraisal tool for Cross-Sectional Studies (AXIS tool) (Downes et al., 2016)
(Table S2). Critical Appraisal Skills Programme (CASP) tool was used to evaluate the case-control studies (CASP, 2018) (Table S3), while the Cochrane risk-of-bias tool for randomized trials (RoB 2) was used to appraise randomized clinical/controlled trials (RCTs) studies (Higgins et al., 2011) (Table S4). The quality and risk of bias of the selected animal studies included in this systematic review were assessed using the Systematic Review Centre for Laboratory animal Experimentation Risk of Bias (SYRCLE RoB tool) (Hooijmans et al., 2014) (Table S5). Unfortunately, currently, there is no wellvalidated critical appraisal tool for the validation and computational studies included in this review.
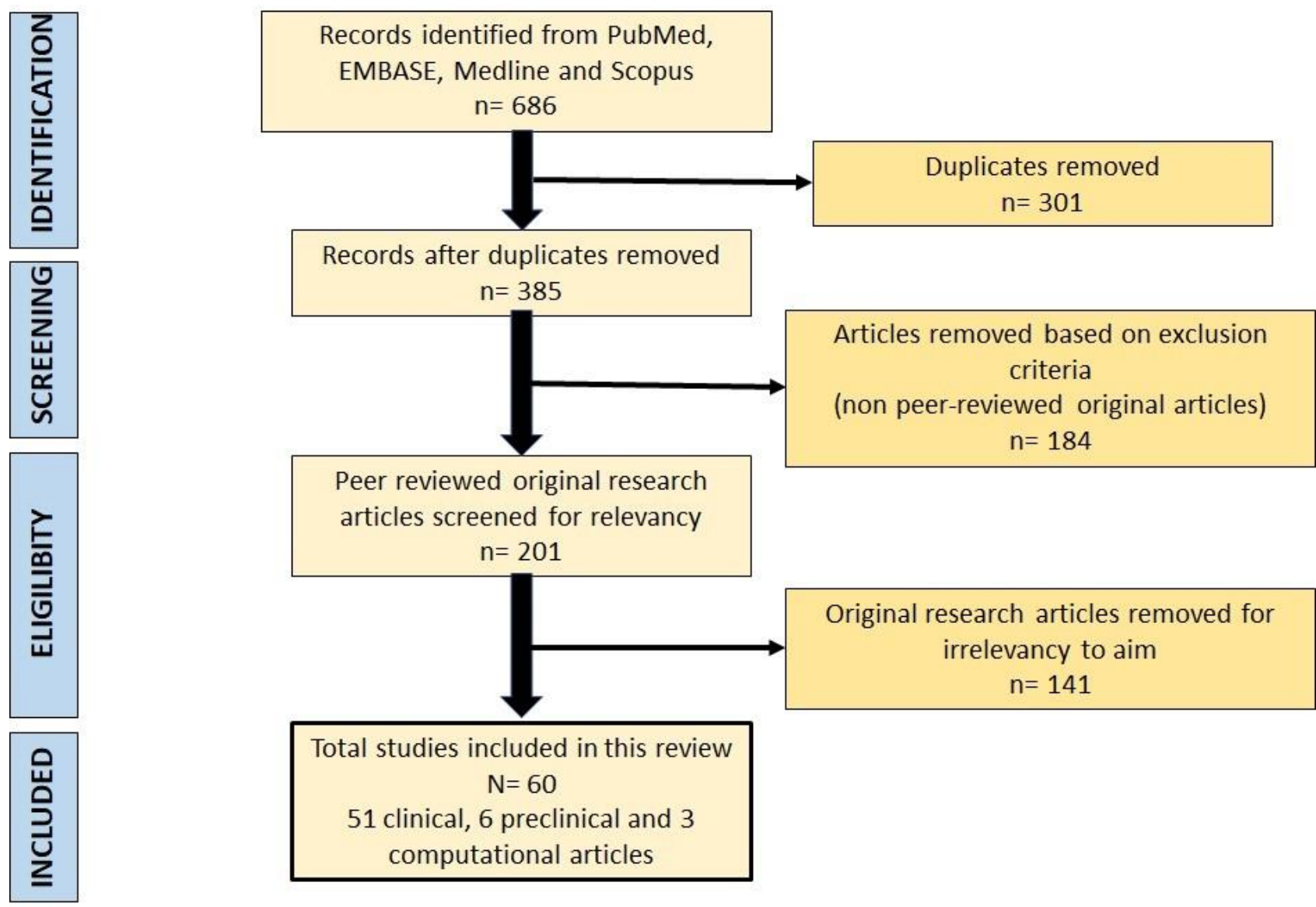

Total studies included in this review $N=60$

51 clinical, 6 preclinical and 3 computational articles

Figure 1. Study selection based on PRISMA guidelines.

\subsection{RESULTS}

The initial literature searches retrieved 686 articles: 89 articles from PubMed, 186 articles from EMBASE, 316 articles from Scopus and 95 articles from Medline. Three hundred and one duplicated articles were removed, and 385 articles were screened based on the exclusion criteria for peer-reviewed original research articles only. Finally, the abstracts of the 201 articles were screened for relevancy, where 141 articles were found to be irrelevant to the aim of this systematic review; their investigation was not focused on traumatic brain injury and was not investigated in Malaysia. To be noted, there were 5 case reports identified (before the exclusion criteria) that were relevant to the aim of this review but were not included for critical appraisal as case reports provide bias and insufficient information for effective evaluation of the findings.

Thus, a total of 60 studies were selected for critical appraisal as per PRISMA guidelines (Figure 1) and were 
systematically evaluated in this review. The 60 articles were further categorized into 17 clinical, 34 epidemiology studies, 6 preclinical animal studies and 3 computational model studies for ease of evaluation. The characteristics and significant findings of the selected studies were summarized in Table 1.

\subsection{Publication Overview of Population Studies}

The human/population studies included 34 epidemiological studies which can be further characterized into 3 case-control, 7 prospective cohorts, 6 prospective longitudinal, 7 retrospective and 11 crosssectional studies, as well as 17 clinical studies which included 7 randomized controlled trials (RCT), 9 prospective observational and 1 validation studies (Table 1). There was a wide range in the type of population studies conducted in Malaysia, with epidemiological studies, mainly cross-sectional studies, is the most sought-after form of study methodology and clinical studies, especially validation studies, being the least investigated thus far (Figure 2B). Population-based research on $\mathrm{TBI}$ in Malaysia has increased at an exponential rate every 5 years (Figure 2A), starting with the first publication recorded in 1988 by Pratap-Chand and his colleagues, that investigated the diagnostic usage of cognitive evoked potential to determine cognitive dysfunction after a concussion (Pratap-Chand et al., 1988) (Table 1).
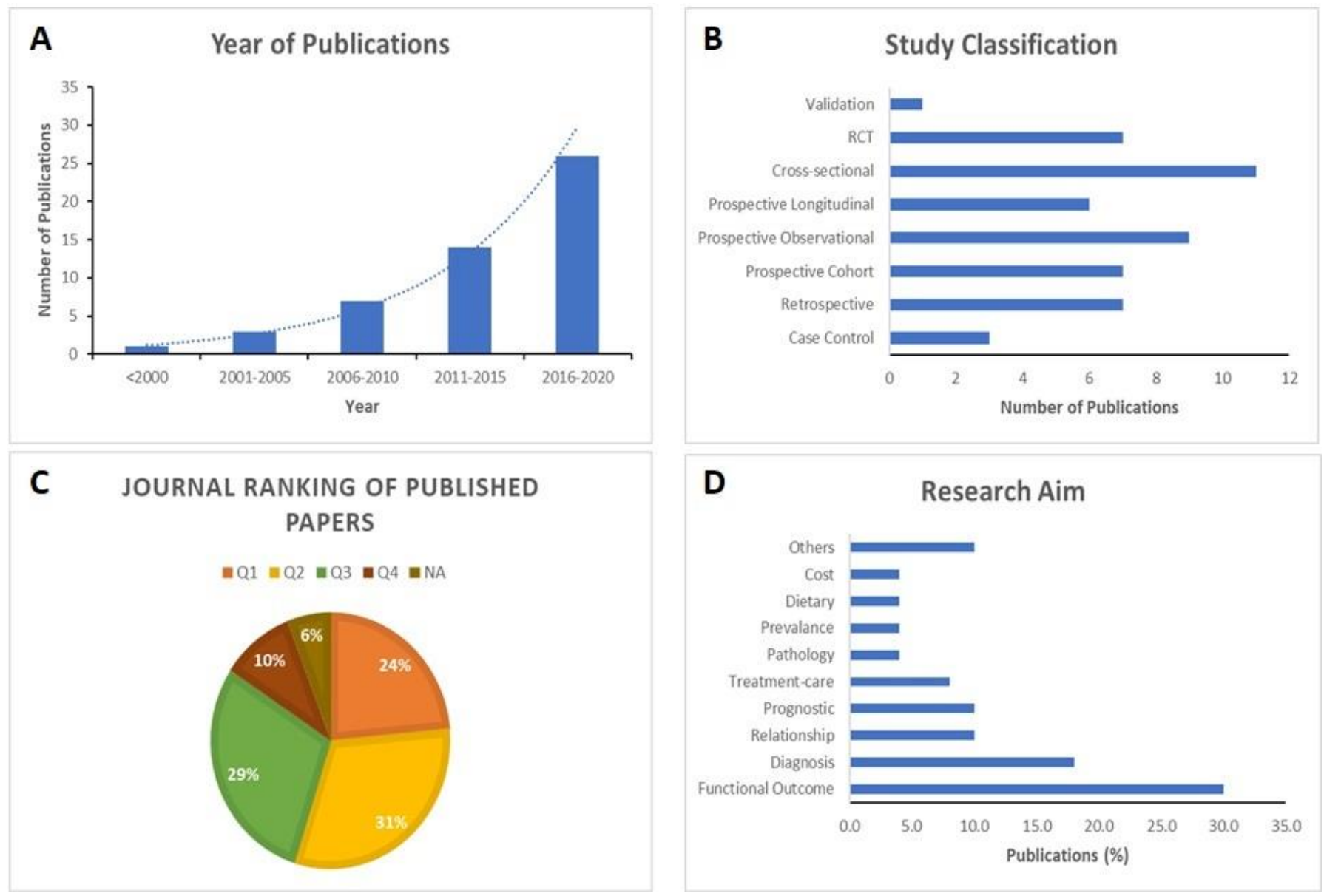

Figure 2. Publication characteristics. (A) A bar chart showing the number of publications produced each year, grouped every 5 years with an exponential line; (B) A bar chart showing the types of population based studies performed in Malaysia; (C) A pie chart showing the percentage of publication published within each SClmago journal ranking; (D) A bar chart showing the different research aims explored by the publications in percentage.

Most researchers chose to focus their investigations on the functional outcome post TBI (30\%), followed by diagnostic (18\%), prognostic (10\%) and relationship (10\%) studies and finally an almost equal spread in all other areas of investigations (Figure 2D). Studies whereby their aim of investigation was in rehabilitation, quality of life of patients or caregivers, epidemiology and tool assessment, had only a single study in each 
Table 1. Study characteristics and the significant findings of articles included in this systematic review.

\begin{tabular}{|c|c|c|c|c|c|}
\hline Type of study & Research aim & Sample & TBI characteristics & Significant findings & References \\
\hline \multirow[t]{3}{*}{ Case Control } & $\begin{array}{l}\text { Functional } \\
\text { Outcome }\end{array}$ & $8-14$ years; $29 \mathrm{M}, 6 \mathrm{~F}$ & Moderate and Severe & Gait performance under dual task affected post TBI & $\begin{array}{l}\text { (Abdul Rahman et al., } \\
\underline{2018} \text { ) }\end{array}$ \\
\hline & $\begin{array}{l}\text { Functional } \\
\text { Outcome }\end{array}$ & $8-14$ years; $31 \mathrm{M}, 7 \mathrm{~F}$ & Moderate and Severe & $\begin{array}{l}\text { Concurrent task affects postural control performance in TBI } \\
\text { children }\end{array}$ & $\begin{array}{l}\text { (Abdul Rahman et al., } \\
\underline{\text { 2019) }}\end{array}$ \\
\hline & $\begin{array}{l}\text { Quality of Life } \\
\text { (QoL) }\end{array}$ & $\begin{array}{l}18-65 \text { years; } 54 \mathrm{M}, \\
10 \mathrm{~F}\end{array}$ & $\begin{array}{l}\text { Mild, Moderate and } \\
\text { Severe }\end{array}$ & Post-TBI olfactory dysfunction significantly lowered QoL & (Ahmedy et al., 2020) \\
\hline \multirow[t]{6}{*}{$\begin{array}{l}\text { Prospective } \\
\text { Longitudinal }\end{array}$} & $\begin{array}{l}\text { Rehabilitation } \\
\text { service }\end{array}$ & $\begin{array}{l}18 \text { below years; } \\
\text { unspecified }\end{array}$ & $\begin{array}{l}\text { Mild-to-Moderate } \\
\text { and Severe }\end{array}$ & $\begin{array}{l}\text { Poor paramedical, medical and rehabilitation care slows down } \\
\text { recovery post TBI in children and leads to persistent } \\
\text { neuropsychological deficits }\end{array}$ & (Abdullah et al., 2005) \\
\hline & $\begin{array}{l}\text { Functional } \\
\text { Outcome }\end{array}$ & $\begin{array}{l}18-53 \text { years; } 69 \mathrm{M}, \\
11 \mathrm{~F}\end{array}$ & Mild & $\begin{array}{l}\text { Significant use of DTI as an imaging biomarker and indicator of } \\
\text { white matter damage occurring in the context of mild TBI }\end{array}$ & $\begin{array}{l}\text { (Veeramuthu et al., } \\
\underline{2015} \text { ) }\end{array}$ \\
\hline & Pathology & $18-53$ years; $42 \mathrm{M}, 6 \mathrm{~F}$ & Mild & $\begin{array}{l}\text { BDNF rs6265 Val66Met polymorphism influences specific } \\
\text { neurocognitive outcomes in patients with mild TBI }\end{array}$ & (Narayanan et al., \\
\hline & Relationship & $\begin{array}{l}18 \text { above years; } 36 \mathrm{M} \text {, } \\
5 \mathrm{~F}\end{array}$ & Mild & $\begin{array}{l}\text { The presence of MF injury without any intracranial traumatic } \\
\text { lesions in patients with mild TBI increases the risk of short- } \\
\text { and long-term neurocognitive derangements }\end{array}$ & $\begin{array}{l}\text { (Veeramuthu et al., } \\
\underline{2016)}\end{array}$ \\
\hline & $\begin{array}{l}\text { Functional } \\
\text { Outcome }\end{array}$ & $\begin{array}{l}18 \text { above years; } 54 \mathrm{M} \text {, } \\
7 \mathrm{~F}\end{array}$ & Mild & $\begin{array}{l}\text { Complicated mild TBI recovered with time while } \\
\text { uncomplicated mild TBI showed slower recovery in memory, } \\
\text { visuospatial processing, and executive functions }\end{array}$ & $\begin{array}{l}\text { (Veeramuthu et al., } \\
\underline{2017)}\end{array}$ \\
\hline & Pathology & $\begin{array}{l}18 \text { above years; } 37 \mathrm{M}, \\
24 \mathrm{~F}\end{array}$ & Mild & $\begin{array}{l}\text { The ratio of NAA and NAAG has potential to serve as a } \\
\text { biomarker as it discriminates between the complicated and } \\
\text { uncomplicated cases of mild TBI }\end{array}$ & $\begin{array}{l}\text { (Veeramuthu et al., } \\
\underline{\text { 2018) }}\end{array}$ \\
\hline \multirow[t]{4}{*}{ Cross sectional } & Prognostic & $\begin{array}{l}\text { 13-81 years; } 21 \mathrm{M}, \\
10 \mathrm{~F}\end{array}$ & Moderate and Severe & $\begin{array}{l}\text { No direct correlation between predictors on the first CT scan } \\
\text { and the follow-up }\end{array}$ & (Kiflie et al., 2006) \\
\hline & Prognostic & $\begin{array}{l}14-72 \text { years; } 70 \mathrm{M}, \\
11 \mathrm{~F}\end{array}$ & $\begin{array}{l}\text { Mild, Moderate and } \\
\text { Severe }\end{array}$ & $\begin{array}{l}\text { Early detection of (10\%) DTICH and (42\%) PTBI in older age } \\
\text { group patient }\end{array}$ & (Jeng et al., 2008) \\
\hline & Prognostic & $\begin{array}{l}2-16 \text { years; } 123 \mathrm{M}, \\
23 \mathrm{~F}\end{array}$ & Severe & $\begin{array}{l}\text { Hyperglycaemia, prolonged PT ratio and leucocytosis were } \\
\text { associated with poorer outcome post TBI }\end{array}$ & (Kan et al., 2009) \\
\hline & Diagnosis & $0-3$ years; ratio $M>F$ & Moderate and Severe & $\begin{array}{l}\text { Retinal haemorrhages and seizures were common physical } \\
\text { signs related to the non-accidental as compared to the } \\
\text { accidental TBI }\end{array}$ & (Hafiz \& Saffari, 2011) \\
\hline
\end{tabular}




\begin{tabular}{|c|c|c|c|c|c|}
\hline & $\begin{array}{l}\text { Functional } \\
\text { Outcome }\end{array}$ & $\begin{array}{l}18 \text { above years; } 73 \mathrm{M}, \\
27 \mathrm{~F}\end{array}$ & $\begin{array}{l}\text { Mild, Moderate and } \\
\text { Severe }\end{array}$ & $\begin{array}{l}\text { Extracranial concomitant injuries AIS grade } \geq 3 \text { influenced the } \\
\text { long-term functional outcome at } 18 \text { months }\end{array}$ & (Leong et al., 2013) \\
\hline & $\begin{array}{l}\text { Functional } \\
\text { Outcome }\end{array}$ & $15-60$ years; $31 \mathrm{M}, 9 \mathrm{~F}$ & $\begin{array}{l}\text { Mild and Moderate- } \\
\text { to-Severe }\end{array}$ & $\begin{array}{l}\text { Cognitive dysfunction prevalent in TBI patients and is } \\
\text { dependent on severity of } \mathrm{TBI}\end{array}$ & (Ali et al., 2013) \\
\hline & Caregivers & $\begin{array}{l}18 \text { above years; } \\
139 \mathrm{M}, 143 \mathrm{~F}\end{array}$ & $\begin{array}{l}\text { Mild, Moderate and } \\
\text { Severe }\end{array}$ & $\begin{array}{l}\text { High risk of strain due to lower income and care for patients } \\
\text { with significant cognitive and neurobehavioral disturbances }\end{array}$ & (Mazlan et al., 2016) \\
\hline & $\begin{array}{l}\text { Functional } \\
\text { Outcome }\end{array}$ & $\begin{array}{l}18 \text { above years; } 85 \mathrm{M}, \\
16 \mathrm{~F}\end{array}$ & $\begin{array}{l}\text { Mild, Moderate and } \\
\text { Severe }\end{array}$ & $\begin{array}{l}\text { Duration of injury was associated with depression while } \\
\text { mechanism of trauma was associated with anxiety in TBI }\end{array}$ & (Abdullah et al., 2018) \\
\hline & Prevalence & $\begin{array}{l}16-84 \text { years; } 133 \mathrm{M}, \\
76 \mathrm{~F}\end{array}$ & Mild & $\begin{array}{l}\text { Less than } 10 \% \text { of patients with mild TBI had PCS after } 6 \\
\text { months' following trauma }\end{array}$ & $\begin{array}{l}\text { (Balakrishnan et al., } \\
\text { 2019) }\end{array}$ \\
\hline & $\begin{array}{l}\text { Functional } \\
\text { Outcome }\end{array}$ & $\begin{array}{l}18 \text { above years; } 85 \mathrm{M}, \\
16 \mathrm{~F}\end{array}$ & $\begin{array}{l}\text { Mild, Moderate and } \\
\text { Severe }\end{array}$ & $\begin{array}{l}\text { The Malay version of HADS is a valid screening tool for } \\
\text { depression and anxiety among Malaysian TBI population }\end{array}$ & (Abdullah et al., 2019) \\
\hline & Dietary & $\begin{array}{l}20-60 \text { years; } 28 \mathrm{M}, \\
22 \mathrm{~F}\end{array}$ & Mild and Moderate & Hospitalized TBI patients were at risk to develop malnutrition & (Abdullah et al., 2020) \\
\hline \multirow[t]{7}{*}{$\begin{array}{l}\text { Prospective } \\
\text { cohort }\end{array}$} & Prevalence & $\begin{array}{l}\text { 14-72 years; } 1251 \mathrm{M}, \\
328 \mathrm{~F}\end{array}$ & Moderate and Severe & $\begin{array}{l}\text { Contrecoup injury is not uncommon in cases of temporal bone } \\
\text { fracture, and is significantly associated with petrous temporal } \\
\text { bone fracture }\end{array}$ & (Asha'Ari et al., 2011) \\
\hline & Diagnosis & $\begin{array}{l}18-65 \text { years; } 244 \mathrm{M}, \\
50 \mathrm{~F}\end{array}$ & $\begin{array}{l}\text { Mild, Moderate and } \\
\text { Severe }\end{array}$ & $\begin{array}{l}\text { Isolated TBI alone may cause a significant elevation in blood } \\
\text { glucose levels which was a predictor of poorer outcomes }\end{array}$ & (Haron et al., 2011) \\
\hline & Diagnosis & $\begin{array}{l}18 \text { above years; } 37 \mathrm{M}, \\
7 \mathrm{~F}\end{array}$ & Severe & $\begin{array}{l}\text { CSF NOx levels may be used to predict ICP readings as well as } \\
\text { CT scan severity of patients with severe TBI }\end{array}$ & $\begin{array}{l}\text { (Kandasamy et al., } \\
\underline{2013} \text { ) }\end{array}$ \\
\hline & Prognostic & $\begin{array}{l}18 \text { above years; } \\
94 \mathrm{M}, 16 \mathrm{~F}\end{array}$ & Severe & $\begin{array}{l}\text { Postoperative hypoxia, unmaintained cerebral perfusion } \\
\text { pressure and unstable blood pressure are independent } \\
\text { predictors of poor outcome in severe TBI after decompressive } \\
\text { craniectomy }\end{array}$ & (Sharda et al., 2014) \\
\hline & $\begin{array}{l}\text { Functional } \\
\text { Outcome }\end{array}$ & $13-65$ years; $19 \mathrm{M}, 2 \mathrm{~F}$ & Mild & $\begin{array}{l}\text { The visuospatial and sensory motor domain of cognitive } \\
\text { deficits persist over time and possibly modulated by ApoE e4 }\end{array}$ & $\begin{array}{l}\text { (Veeramuthu et al., } \\
\text { 2014) }\end{array}$ \\
\hline & $\begin{array}{l}\text { Functional } \\
\text { Outcome }\end{array}$ & $\begin{array}{l}18 \text { above years; } 22 \mathrm{M}, \\
14 \mathrm{~F}\end{array}$ & Mild & $\begin{array}{l}\text { The latency of P300 was significantly prolonged in early mild } \\
\text { TBI patients who improved over time }\end{array}$ & $\begin{array}{l}\text { (Nandrajog et al., } \\
\text { 2017) }\end{array}$ \\
\hline & $\begin{array}{l}\text { Functional } \\
\text { Outcome }\end{array}$ & $16-73$ years; $27 \mathrm{M}, 6 \mathrm{~F}$ & Severe & $\begin{array}{l}\text { The logistic regression model, length of stay in incentive care } \\
\text { unit and duration on ventilator were good predictors of the } \\
\text { functional outcomes post TBI }\end{array}$ & (Ludin et al., 2019) \\
\hline $\begin{array}{l}\text { Prospective } \\
\text { Observational }\end{array}$ & $\begin{array}{l}\text { Functional } \\
\text { Outcome }\end{array}$ & $6-13$ years; $27 \mathrm{M}, 9 \mathrm{~F}$ & $\begin{array}{l}\text { Mild, Moderate and } \\
\text { Severe }\end{array}$ & $\begin{array}{l}\text { Midline shift, duration of coma and duration of transport were } \\
\text { found to be significant variables associated with bad outcome }\end{array}$ & $\begin{array}{l}\text { (Kumaraswamy et al., } \\
\text { 2002) }\end{array}$ \\
\hline
\end{tabular}

NEUROSCIENCE RESEARCH NOTES | 2020 | VOLUME 3 | ISSUE 4 | PAGE 6 


\begin{tabular}{|c|c|c|c|c|c|}
\hline & Treatment-care & $\begin{array}{l}12-30 \text { years; } 69 \mathrm{M}, \\
13 \mathrm{~F}\end{array}$ & Severe & $\begin{array}{l}\text { Significant difference in proportions of good outcomes } \\
\text { between the multimodality group, patients that underwent a } \\
\text { single intracranial-based monitoring method and the group } \\
\text { that received no monitoring }\end{array}$ & (Isa et al., 2003) \\
\hline & Cost & $18-75$ years; $57 \mathrm{M}, 5 \mathrm{~F}$ & Severe & $\begin{array}{l}\text { The application of } \mathrm{M} 3 \text { for severe TBI was more cost-effective } \\
\text { than BNM }\end{array}$ & (Ibrahim et al., 2007) \\
\hline & Prognostic & $17-69$ years; $47 \mathrm{M}, 5 \mathrm{~F}$ & Severe & $\begin{array}{l}\text { The outcome at } 6 \text { months post treatment between the two } \\
\text { modality groups was not statistically significant }\end{array}$ & (Idris et al., 2007) \\
\hline & $\begin{array}{l}\text { Functional } \\
\text { Outcome }\end{array}$ & $\begin{array}{l}18 \text { above years; } 61 \mathrm{M}, \\
11 \mathrm{~F}\end{array}$ & Severe & $\begin{array}{l}\text { Higher risk of mortality, worse GCS improvement upon } \\
\text { discharge and longer ICU stays in ICP group compared to } \\
\text { Intubation group }\end{array}$ & (Liew et al., 2009) \\
\hline & $\begin{array}{l}\text { Functional } \\
\text { Outcome }\end{array}$ & $\begin{array}{l}2-87 \text { years; } 137 \mathrm{M}, \\
20 \mathrm{~F}\end{array}$ & $\begin{array}{l}\text { Mild, Moderate and } \\
\text { Severe }\end{array}$ & $\begin{array}{l}\text { Younger and intubated patients were at a higher risk of } \\
\text { developing early post-traumatic seizures }\end{array}$ & (Chan et al., 2010) \\
\hline & Diagnosis & $\begin{array}{l}18 \text { above years; } \\
227 \mathrm{M}, 52 \mathrm{~F}\end{array}$ & Mild & $\begin{array}{l}\text { Patients with mild TBI and a normal neurological examination, } \\
\text { a repeat cranial CT is not indicated unless the repeat head CT } \\
\text { worsens }\end{array}$ & $\begin{array}{l}\text { (Sharifuddin et al., } \\
\underline{2012)}\end{array}$ \\
\hline & Treatment-care & $14-74$ years; $27 \mathrm{M}, 5 \mathrm{~F}$ & Severe & $\begin{array}{l}\text { Direct regional brain hypothermia appears safe, feasible and } \\
\text { maybe beneficial in treating severely head-injured patients }\end{array}$ & (Idris et al., 2014) \\
\hline & Diagnosis & $\begin{array}{l}14-60 \text { years; } \\
12 \mathrm{M}, 8 \mathrm{~F}\end{array}$ & Mild & $\begin{array}{l}\text { P300 latency and amplitude is a sensitive measure of cerebral } \\
\text { dysfunction in concussive head injuries. }\end{array}$ & $\begin{array}{l}\text { (Pratap-Chand et al., } \\
\text { 1988) }\end{array}$ \\
\hline \multirow[t]{4}{*}{ RCT } & $\begin{array}{l}\text { Functional } \\
\text { Outcome }\end{array}$ & $16-55$ years; $18 \mathrm{M}, 1 \mathrm{~F}$ & Mild and Moderate & $\begin{array}{l}\text { No clear relationship between possession of the } \varepsilon 4 \text { allele and } \\
\text { poorer neuropsychological performance in small group of } \\
\text { Malaysians with mild-to-moderate TBI }\end{array}$ & (Shadli et al., 2011) \\
\hline & Diagnosis & $\begin{array}{l}16-50 \text { years; } 15 \mathrm{M}, \\
15 \mathrm{~F}\end{array}$ & $\begin{array}{l}\text { Mild, Moderate and } \\
\text { Severe }\end{array}$ & $\begin{array}{l}\text { Variations in the levels of protein signature can be used to } \\
\text { differentiate the severity of head injury }\end{array}$ & (Anada et al., 2018) \\
\hline & Diagnosis & $\begin{array}{l}18 \text { above years; } 18 \mathrm{M} \text {, } \\
7 \mathrm{~F}\end{array}$ & Moderate & $\begin{array}{l}\text { Data from moderate TBI cases was explored to refine the } \\
\text { decision boundary (hyperplane) by anomaly support vectors } \\
\text { (ASVs) }\end{array}$ & $\begin{array}{l}\text { (Rasheed \& Tang, } \\
\underline{2020})\end{array}$ \\
\hline & Diagnosis & $\begin{array}{l}\text { 18-65 years; } \\
\text { unspecified }\end{array}$ & Moderate & $\begin{array}{l}\text { CNN is a potential substitution for EEG machine learning } \\
\text { application which required complex procedure for } \\
\text { preprocessing of the signals and feature extraction }\end{array}$ & (Lai et al., 2020) \\
\hline
\end{tabular}




\begin{tabular}{|c|c|c|c|c|c|}
\hline & Dietary & $15-75$ years; $33 \mathrm{M}, 3 \mathrm{~F}$ & Moderate and Severe & $\begin{array}{l}\text { These findings indicate the potential of immunonutrition } \\
\text { reducing cytokines and increasing antioxidant indices in } \\
\text { patients with TBI }\end{array}$ & (Rai et al., 2017) \\
\hline & Treatment-care & $\begin{array}{l}18 \text { above years; } 55 \mathrm{M}, \\
8 \mathrm{~F}\end{array}$ & Severe & $\begin{array}{l}\text { BF therapy showed better effects in maintaining higher } \\
\text { electrolyte parameters and reducing the trend toward } \\
\text { hyperchloremic metabolic acidosis than the NS therapy during } \\
\text { prolonged fluid therapy for postoperative TBI patients }\end{array}$ & (M. H. Hassan et al., \\
\hline & Treatment-care & $\begin{array}{l}18-60 \text { years; } 89 \mathrm{M}, \\
21 \mathrm{~F}\end{array}$ & Severe & $\begin{array}{l}\text { TIVA/TCI propofol anaesthesia was comparable in the } \\
\text { outcome parameters with sevoflurane anaesthesia }\end{array}$ & $\begin{array}{l}\text { (W. M. N. W. Hassan } \\
\text { et al., 2017) }\end{array}$ \\
\hline \multirow[t]{2}{*}{ Retrospective } & Cost & $18-54$ years; $45 \mathrm{M}, 4 \mathrm{~F}$ & $\begin{array}{l}\text { Mild, Moderate and } \\
\text { Severe }\end{array}$ & $\begin{array}{l}\text { The mean cost of treatment for traumatic head injury is high } \\
\text { compared to the per capita income of RM37,900 in } 2016\end{array}$ & (You et al., 2018) \\
\hline & Relationship & $\begin{array}{l}18 \text { above years; } \\
304 \mathrm{M}, 44 \mathrm{~F}\end{array}$ & Mild & Facial injuries were significantly associated with mild TBI & (Razak et al., 2017) \\
\hline \multirow[t]{2}{*}{$\begin{array}{l}\text { Retrospective } \\
\text { cohort }\end{array}$} & Diagnosis & $\begin{array}{l}18 \text { below years; } \\
199 \mathrm{M}, 75 \mathrm{~F}\end{array}$ & Mild & $\begin{array}{l}\text { Headache, dizziness and scalp haematoma were identified as } \\
\text { important clinical variables that can be used to predict TBI on } \\
\text { a CT scan of paediatric minor head injury }\end{array}$ & $\begin{array}{l}\text { (Song, Ahmad, Siti- } \\
\text { Azrin, et al., 2019) }\end{array}$ \\
\hline & Relationship & $\begin{array}{l}18 \text { below years; } \\
100 \mathrm{M}, 35 \mathrm{~F}\end{array}$ & Mild & $\begin{array}{l}\text { Paediatric patients who present with non-isolated vomiting } \\
\text { symptoms post minor blunt head trauma were at higher risk } \\
\text { of developing } \mathrm{TBI} \text { and thus require immediate CT scan }\end{array}$ & $\begin{array}{l}\text { (Song, Ahmad, } \\
\text { Hamid, et al., 2019) }\end{array}$ \\
\hline \multirow[t]{2}{*}{$\begin{array}{l}\text { Retrospective } \\
\text { cross sectional }\end{array}$} & Relationship & $\begin{array}{l}1-86 \text { years; } 381 \mathrm{M}, \\
87 \mathrm{~F}\end{array}$ & $\begin{array}{l}\text { Mild, Moderate and } \\
\text { Severe }\end{array}$ & $\begin{array}{l}\text { Patients with maxillofacial injuries with or without facial } \\
\text { fractures are at risk of acute or delayed traumatic brain injury }\end{array}$ & (Rajandram et al., \\
\hline & Epidemiology & $\begin{array}{l}0-19 \text { years; } 594 \mathrm{M}, \\
148 \mathrm{~F}\end{array}$ & $\begin{array}{l}\text { Mild, Moderate and } \\
\text { Severe }\end{array}$ & $\begin{array}{l}\text { Most brain injuries occurred among older male children, with } \\
\text { traffic, specifically motorcycle-related, accidents being the } \\
\text { main mode of injury }\end{array}$ & (Tay et al., 2016) \\
\hline $\begin{array}{l}\text { Retrospective } \\
\text { Observational }\end{array}$ & Relationship & $12-78$ years; $41 \mathrm{M}, 3 \mathrm{~F}$ & Severe & $\begin{array}{l}\text { Leucocytosis on admission was associated with poor } \\
\text { outcomes where patients with higher total white counts on } \\
\text { presentation attaining lower GOSE scores }\end{array}$ & (Vijian et al., 2020) \\
\hline Validation & Assessment Tool & $\begin{array}{l}18 \text { above years; } 93 \mathrm{M}, \\
21 \mathrm{~F}\end{array}$ & Mild & $\begin{array}{l}\text { S-NAB is an acceptable and reliable screening tool for the } \\
\text { measurement of mild cognitive deficits in } \mathrm{MTBI} \text { population of } \\
\text { Malaysia }\end{array}$ & (Hamzah et al., 2019) \\
\hline Preclinical Animal & Intervention & $11-13$ weeks; 60M & $\begin{array}{l}\text { Weight drop model; } \\
\text { Severe }\end{array}$ & $\begin{array}{l}\text { PX-coated PLGA nanoparticles effectively delivered BDNF into } \\
\text { the brain, and improved neurological and cognitive deficits } \\
\text { post TBI }\end{array}$ & $\begin{array}{l}\text { (Khalin, Alyautdin, et } \\
\text { al., 2016) }\end{array}$ \\
\hline
\end{tabular}




\begin{tabular}{|c|c|c|c|c|c|}
\hline & $\begin{array}{l}\text { Functional } \\
\text { Outcome }\end{array}$ & 11-13 weeks; $62 \mathrm{M}$ & $\begin{array}{l}\text { Weight drop model; } \\
\text { Severe }\end{array}$ & $\begin{array}{l}\text { Cognitive disorders in mice with severe closed head injury } \\
\text { could be detected using passive avoidance test on day } 7 \text { after } \\
\text { injury }\end{array}$ & $\begin{array}{l}\text { (Khalin, Jamari, et al., } \\
\underline{2016)}\end{array}$ \\
\hline & Intervention & 11-13 weeks; 60M & FPI; unspecified & $\begin{array}{l}\text { DA levels consistently increased at all stages due to NBOT } \\
\text { which also controls oxidative damage and over activation of } \\
\text { glutamate }\end{array}$ & $\begin{array}{l}\text { (Muthuraju et al., } \\
\underline{2014} \text { ) }\end{array}$ \\
\hline & Intervention & 11-13 weeks; 38M & FPI; unspecified & $\begin{array}{l}\text { FPI mice with IE showed less dead cells as compared to FPI } \\
\text { mice without IE, with a complete restoration in locomotive } \\
\text { activity }\end{array}$ & (Muthuraju et al., \\
\hline & Intervention & 11-13 weeks; 54M & FPI; unspecified & $\begin{array}{l}\text { TBI group showed severe morphological changes and } \\
\text { neuronal damage as compared to the TBI group exposed to } \\
\text { NBO for } 3 \mathrm{~h}\end{array}$ & $\begin{array}{l}\text { (Muthuraju, Pati, et } \\
\text { al., 2013) }\end{array}$ \\
\hline & Intervention & 11-13 weeks; 96M & FPI; unspecified & $\begin{array}{l}\text { Immediate exposure to NBOT improved LA in terms of } \\
\text { reduced cell death and improved receptor expression as } \\
\text { compared to FPI. }\end{array}$ & $\begin{array}{l}\text { (Muthuraju, Taha, et } \\
\text { al., 2013) }\end{array}$ \\
\hline \multirow[t]{3}{*}{ Computational } & Diagnosis & NA & $\begin{array}{l}\text { Mathematical Model; } \\
\text { NA }\end{array}$ & $\begin{array}{l}\text { The proposed predictive model improves the predictive } \\
\text { performance of TBI }\end{array}$ & (Alanazi et al., 2018) \\
\hline & $\begin{array}{l}\text { Functional } \\
\text { Outcome }\end{array}$ & NA & $\begin{array}{l}\text { Mathematical Model; } \\
\text { NA }\end{array}$ & $\begin{array}{l}\text { This study shows that a simple linear mathematical model can } \\
\text { be used to investigate the important parameters during } \\
\text { soccer heading that affect the brain displacement and } \\
\text { acceleration, }\end{array}$ & (Taha et al., 2015) \\
\hline & Diagnosis & NA & $\begin{array}{l}\text { Mathematical Model; } \\
5 \text { different impact } \\
\text { velocities }\end{array}$ & $\begin{array}{l}\text { The proposed Finite Element software may predict the head } \\
\text { injury mechanism (magnitude of total deformation, maximum } \\
\text { principle stress) on TBI patients skull using computed impact } \\
\text { velocity }\end{array}$ & (Norli et al., 2018) \\
\hline
\end{tabular}

Note: M: Male, F: Female, TBI: traumatic brain injury, DTI: diffuse tensor imaging, BDNF: brain derived neurotrophic factor, MF: maxillofacial, NAA: N-acetylaspartate, NAAG: Nacetylaspartylglutamate, CT: computed tomography, DTICH: Delayed traumatic intracranial haemorrhage, PTBI: progressive traumatic brain injury, PT: Prothrombin Time, GCS: Glasgow Coma Scale, AIS: Abbreviated Injury Scale, PCS: Postconcussion Syndrome, HADS: hospital anxiety and depression scale, CSF: Cerebrospinal fluid, NOx: nitric oxide, ICP:

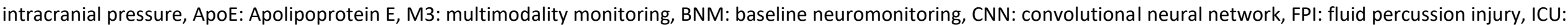

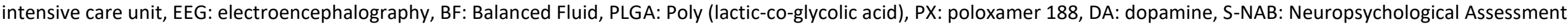
Battery-Screening Module, GOSE: Glasgow Outcome Scale-Extended, NS: Saline-Based Fluid, TIVA: total intravenous anaesthesia, TCI: target-controlled infusion, IE: IntelliCage Exposure, NBOT: Normobaric hyperoxia treatment, NBO: normabaric hyperoxia, LA: Locomotor Activity. 
research aim category, and thus were pooled together under the category 'Others'. Interestingly, only five TBI studies had a follow up extending more than a year; 18 months (Leong et al., 2013) or around 2 years (Abdul Rahman et al., 2019; Abdul Rahman et al., 2018; Ahmedy et al., 2020; Kumaraswamy et al., 2002), which aimed at investigating the functional outcome in patients post $\mathrm{TBI}$, and only one study that investigated the impact on caregivers of TBI patients, with a follow up for more than 5 years (Mazlan et al., 2016). Majority of the studies looked at acute (24-72 hours) or subacute (weeks) effects of TBI, especially those with research aimed at diagnosis after TBI.

Nearly $25 \%$ of the population studies were published in Malaysian journals such as Malaysian Journal of Medical Sciences, and more than $50 \%$ of the population studies were published in high ranking journals; $Q 1$ and Q2 journals, according to SCImago journal ranking (Figure 2C). There was no observable correlation between type of study or research aim with the publication journal ranks. Quality assessments on the publications revealed that the population-based studies had five studies (3 cross-sectional and 2 RCTs) which may be biased due to lack of blinding and sample size justification, while quality assessment of the rest of the population based studies and preclinical animal studies showed unbiased methodology and reporting of their results (see Supplementary S1-S5).

\subsection{Population Sample Overview}

Most of the studies have sampled the adult population (18 years and above); 21 studies had a population average age in their 30s, 15 studies in their 20 s and only 1 study had a mean population age of 46.13 years (Figure 3A). Ten studies investigated TBI in children or in a paediatric population (18 years and below). Four of the population studies had an undefined mean population age, but stated their population age range to be 18 years and above. In most of the studies with a wide age range for participant recruitment, participants in their 20s to $30 \mathrm{~s}$ reported the most TBI cases, especially due to road accidents, which accounts for around $70-90 \%$ of all TBI cases in nearly all the selected population studies. One study by Sharda et al (2014), found that road traffic accidents, especially those involving motorbikes, was the most common cause of TBI among the 12-30 years old age group (Sharda et al., 2014). While the younger population were at higher risk of attaining $\mathrm{TBI}$, some of the selected studies suggested that there was a negative correlation between the outcomes of TBI (especially cognitive effects) and age (Asha'Ari et al., 2011; Sharifuddin et al., 2012;
Veeramuthu et al., 2014; Vijian et al., 2020). In contradiction, some studies also suggested no significant effect between age and functional outcome or prognosis (Abdullah et al., 2005; Abdullah et al., 2018; Kan et al., 2009; Kiflie et al., 2006; Ludin et al., 2019).

Interestingly, when calculating and stratifying the number of participants in each of the studies sample population according to gender, a large gender difference was noticed in the age groups 10s, 20s and 30 s, with males predominating the population by more than 1000 participants in the 20s and 30s age group (Figure 3B). Females were clearly underrepresented in the Malaysian population TBI studies. Nevertheless, a number of studies indicated no significant relationship between gender differences and measures of TBI, except a recent study by Abdullah et al. (2020) that witnessed male TBI patients having a higher calorie intake than their female counterpart at discharge day (Abdullah et al., 2020).

As for racial representation, most of the TBI population studies had a 6:2:1:1 ratio of Malays: Chinese: Indian: Other minorities, respectively. Cumulatively, the Malay population represented $62 \%$ of the pooled sample of all the population studies, with Chinese following at $16 \%$ of the pooled sample, Indians at $12 \%$ and finally the other minority ethnicities such as the indigenous Malaysians making up the remaining $10 \%$ of the pooled sample (Figure $3 \mathrm{C}$ ). Only one study utilized religion as a characteristic of their sample (Abdullah et al., 2018). Twenty-six studies did not identify the ethnicity of their population, while 7 studies had an unequal representation of the Malaysian population ethnicity; only had one or two of the ethnicities represented. Among the studies that had a good ethnicity representation, only two studies suggested that ethnicity heterogeneity had a significant influence on the TBI outcome (Ali et al., 2013; Jeng et al., 2008).

Type of TBI severity was fairly well investigated in the population studies, with severe TBI $(\mathrm{GCS}<8$ ) investigated in $36 \%$ of studies, followed by mild TBI (GCS 13-15) and lastly by moderate TBI (GCS 9-12) (Figure 3D). Only thirteen studies investigated all three TBI severities within their population sample and showed that $\mathrm{TBI}$ severity affects the functional outcome and diagnosis post $\mathrm{TBI}$, whereby severe $\mathrm{TBI}$ showed poorer outcomes.

According to the 2019 road accident statistics, reported by the Royal Malaysian Police (PDRM, 2020a), Selangor 

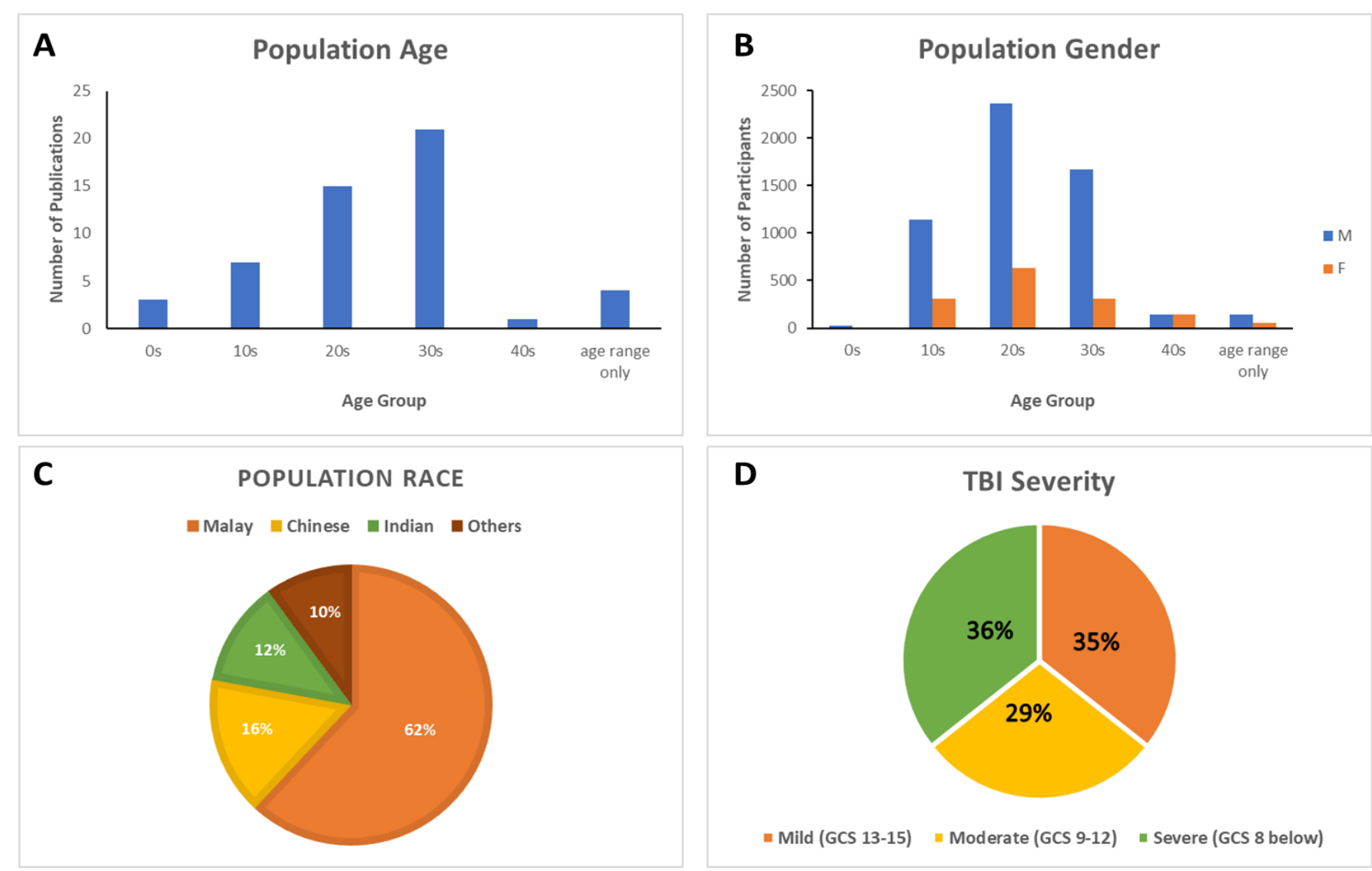

Figure 3. Population characteristics. (A) A bar chart of population age (mean) group versus number of publications; (B) A bar chart of the number of cumulative participants stratified according to gender (M: Male (blue bar), F: Female (orange bar) within each age group; (C) A pie chart showing the distribution of population according to race/ethnicity; (D) A pie chart showing the distribution of TBI severity recorded in the TBI population studies.

had the highest number (darkest orange colour) of road accidents cases followed by Johor and then Wilayah Persekutuan (WP) Kuala Lumpur (Figure 4A). However, the TBI participants sampled for the population studies were mainly from areas surrounding WP Kuala Lumpur with 18 studies, followed by Kelantan with 17 studies (Figure 4B). A large proportion of the studies sampled their TBI population from the University Malaya Medical Centre (UMMC) or from the General Hospital Kuala Lumpur (GHKL), both situated in Kuala Lumpur. In Kelantan, the TBI participants was mainly sampled from the University Sains Malaysia (USM) Hospital. Therefore, the publication affiliations for these TBI studies were majorly from USM (Kelantan campus and hospital) with $23 \mathrm{TBI}$ studies published by their researchers, followed by University Malaya researchers publishing $12 \mathrm{TBI}$ population studies in total (Figure 5). Interestingly, although Jeng et al (2008) sampled his population from GHKL, the sample contained TBI patients from various Malaysian states that were part of referrals to GHKL (Jeng et al., 2008). However, the differences in the Malaysian states were not significantly correlated with the aim of their study.

\subsection{Basic Science Research}

The literature search revealed that basic science research or preclinical research in the TBI field was very scarce in Malaysia, with only 9 studies; 6 animal studies and 3 computational studies, ever to be published and all only within the last decade (Table 1 ). The preclinical animal TBI studies were performed only by two research groups; one from University Malaya with articles published by Khalin I. et al. and the other from University Sains Malaysia with articles published by Muthuraju S. and his colleagues. Both groups used adult (11-13 weeks of age) male mice to investigate functional outcomes and interventions post TBI (Figure 6). Khalin et al. applied the weight drop injury model (Khalin, Alyautdin, et al., 2016; Khalin, Jamari, et al., 2016) while Muthuraju et al. applied the fluid percussion injury (FPI) model to inflict TBI in their animals (Muthuraju et al., 2014; Muthuraju et al., 2012; Muthuraju, Pati, et al., 
2013; Muthuraju, Taha, et al., 2013). While both groups used similar mice breed as their animal model, Khalin et al. used two variations for each of their published studies in 2016; C57BL/6 mice (Khalin, Alyautdin, et al., 2016) and C57BL/6N mice (Khalin, Jamari, et al., 2016), and Muthuraju et al. used the C57BL/J6 mice consistently in all their published studies (Figure 6). Although Khalin et al. claimed that their injury model achieved severe TBI, Muthuraju et al. did not specify their injury severity resulted from their injury model. Regardless, all six of the preclinical studies suggested cognitive or motor deficits as well as neuronal damage that were significantly evident post injury, which may be reversed to sham levels, using different interventions such as BDNF (Khalin, Alyautdin, et al., 2016), normabaric hypoxia treatment (Muthuraju et al., 2014; Muthuraju, Pati, et al., 2013; Muthuraju, Taha, et al.,
2013) and enriched environment (Muthuraju et al., 2012).

The preclinical computational studies had no similarities in methodology or in research group. Based on Table 1, Alazani et al. (2018) was focused on a creating a predictive model for TBI disease classification using mathematical formula and equations (Alanazi et al., 2018), while Taha et al. (2015) had proposed a mathematical model that studies the kinematic parameters surrounding the impact of a soccer ball on a head resulting in TBI (Taha et al., 2015). Similarly, Norli et al. (2018) had developed a virtual software (Finite Element) that may be used to understand and predict the mechanics of head injury in patients based on the impact velocity information available on the sustained TBI (Norli et al., 2018).

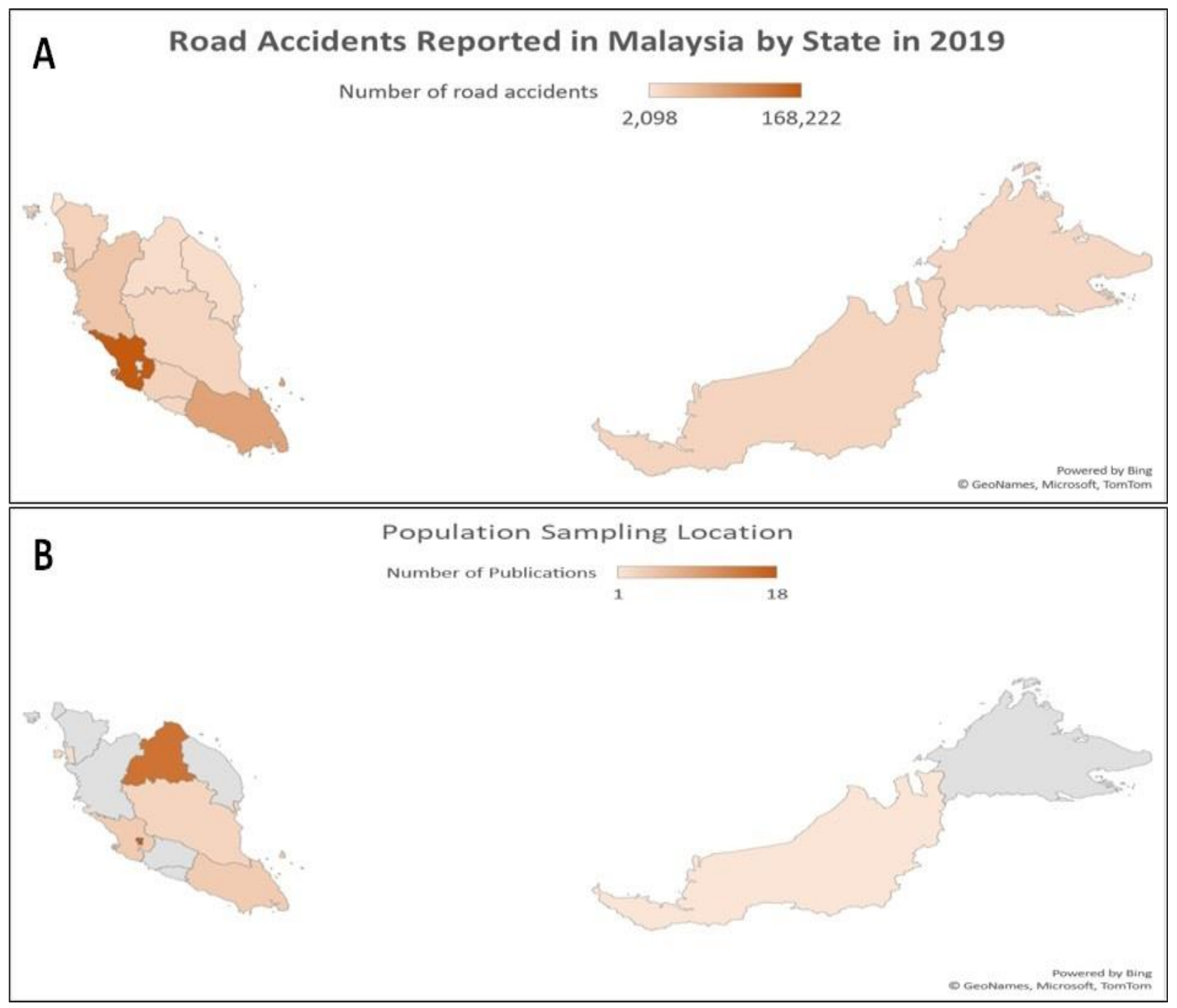

Figure 4. A geographical chart of (A) road accident incidences reported in 2019 and (B) population sampling distributions by publications, in Malaysia. The darker the orange shade, the higher number of $(A)$ incidences or (B) publications. Grey areas signify no incidences or publications recorded. 


\section{Publication Affliation}

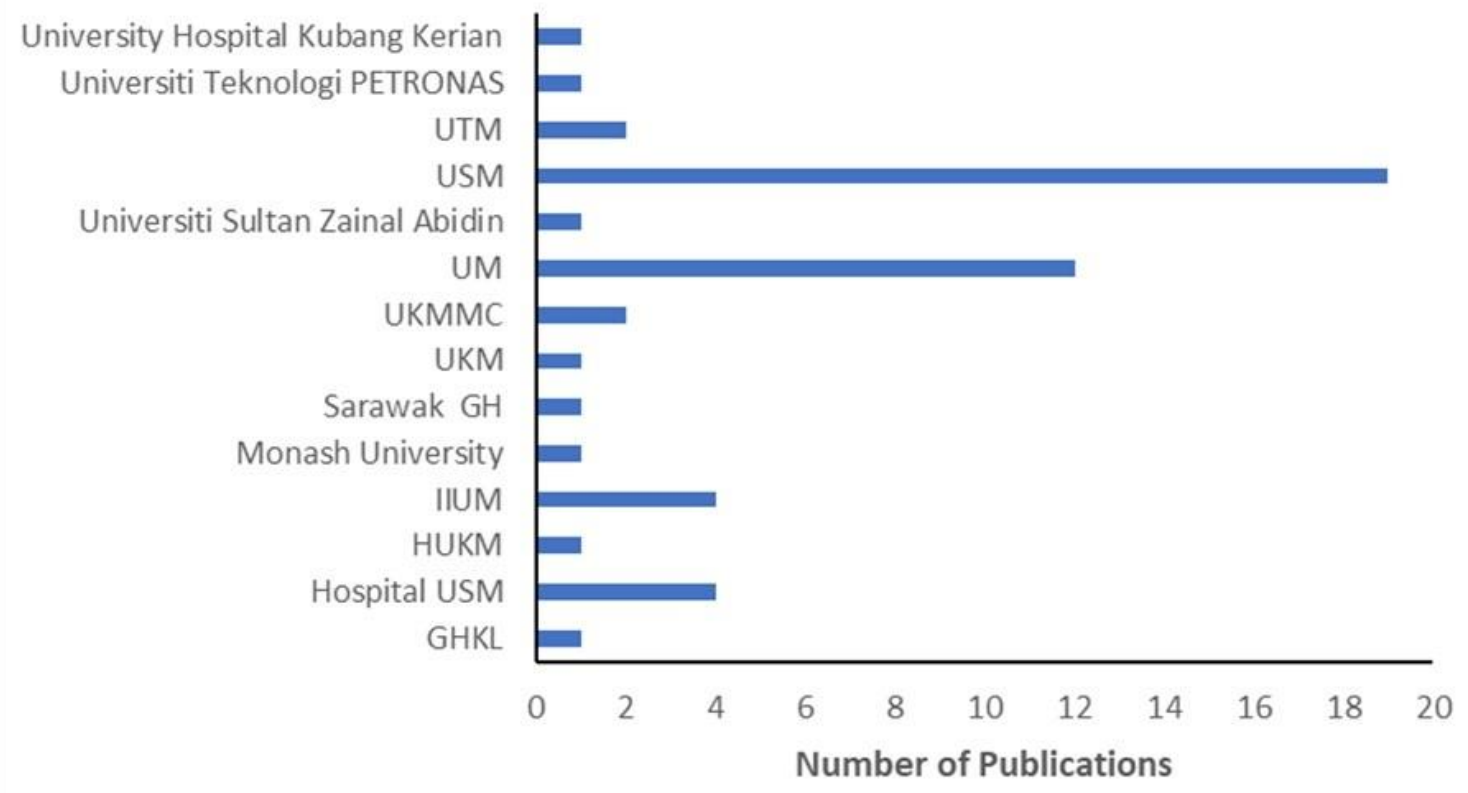

Figure 5. A bar chart of number of publications produced by each institution in Malaysia for population based TBI studies

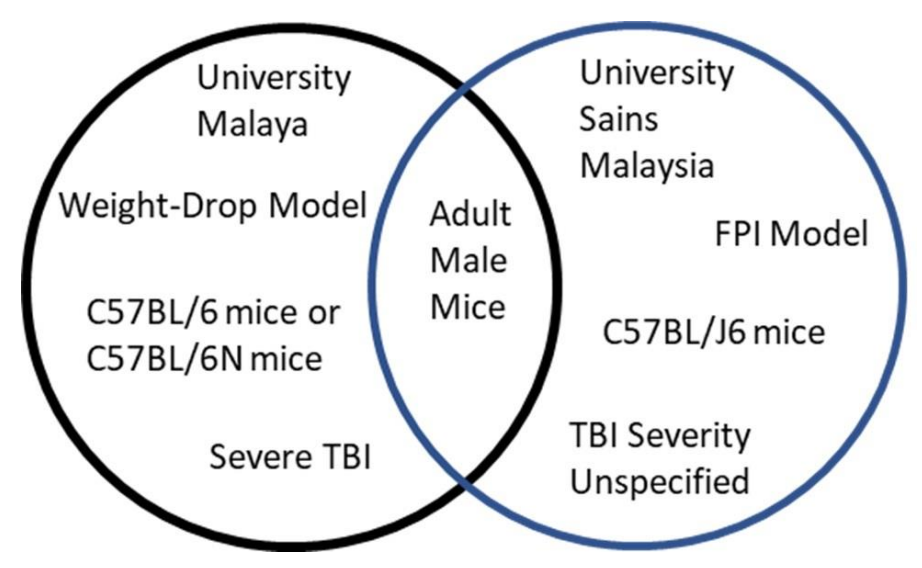

Figure 6. A Venn diagram showing the similarities and differences between the preclinical TBI studies published by two research groups

\subsection{DISCUSSION}

Overall, this systematic review provides a clear and concise overview on the current status of traumatic brain injury research in Malaysia. Evaluation of the available literature revealed that TBI research in Malaysia were relatively scarce compared to other countries such as US and Europe, and population based TBI research outweighed basic TBI research in Malaysia by roughly a 6 to 1 ratio. Nevertheless, the selected list of literature has cohesively concluded that TBI is a devastating disease in Malaysia, caused predominantly by motor vehicle accidents, that results in detrimental and often persisting functional outcomes with poor prognosis, which therefore reduces the quality of life in patients and their caregivers. However, underrepresentation of the actual Malaysian population, small sample size and lack of statistical testing of potential influencing factors such as age, gender and ethnicity, were found to be prominent limitation in many of the selected studies. Similarly, preclinical animal models were only tested by two research groups 
which may provide a narrow basic research scope on TBI.

This review observed an exponential increase in TBI publications in Malaysia within the last two decades, which could be a reflection towards the increased awareness of TBI research globally, as well as the increased number of TBI cases in Malaysia (Jamaluddin et al., 2011). The increment in TBI cases could be an indirect result of Malaysia's economy growth which may enable more Malaysian citizens, especially adolescence, to afford motor vehicles. In conjunction with the increase in TBI cases and awareness, the type of study design and TBI research aims have expanded as well, as more researchers collaborate with hospitals and universities to provide a better understanding of traumatic brain injury within Malaysia and globally. While Malaysian TBI research has been well cited and received in high impact journals, Malaysia is still a couple of steps behind in producing high throughput and high quality TBI research as compared to leading TBI experts in high income countries such as Australia, America, Europe and China (Tropeano et al., 2019). This is alarming as global TBI incidence reports have stated that countries in Southeast Asia, such as Malaysia have the highest number of reported TBI cases, which are majorly due to motor vehicle accidents (Dewan et al., 2018). In support, the latest 2019 Malaysian road accident report by the Royal Malaysian Police (PDRM) have shown that the number of road accidents in Malaysia affected about $1.74 \%$ of the population every year and at an increasing rate of 10,000 to 20,000 cases yearly (PDRM, 2020a). Given that the number of TBI fatalities were decreasing in the past years (PDRM, $\underline{2020 b}$ ), indirectly indicating an increase in TBI survivors, more studies investigating the secondary outcomes post TBI are therefore much needed in Malaysia.

Secondary outcomes of TBI included cognitive deficits, motor impairments, disease progression such as epilepsy and neuropsychiatric disorders, which have all been reported globally (Kozlowski et al., 2013; LuckeWold et al., 2015; Nicholl \& LaFrance, 2009; Rabinowitz \& Levin, 2014) and in Malaysia (Abdul Rahman et al., 2018; Abdullah et al., 2005; Abdullah et al., 2018; Ali et al., 2013; Chan et al., 2010; Kumaraswamy et al., 2002; Liew et al., 2009; Ludin et al., 2019; Nandrajog et al., 2017; Shadli et al., 2011; Veeramuthu et al., 2015; Veeramuthu et al., 2017; Veeramuthu et al., 2014). It is quite well known globally that TBI is not just a static event but an ongoing evolving disease that often leads to functional and psychiatric impairments in the later years following injury (McKee \& Daneshvar, 2015), despite initial recovery. Thus far, only a limited number of studies have investigated this post injury outcome progression, with 2-3 years being the furthest outcome followed up in TBI patients (Abdul Rahman et al., 2019; Abdul Rahman et al., 2018; Ahmedy et al., 2020; Kumaraswamy et al., 2002). Thus, with mental health problems slowly shedding its taboo coat in Malaysia, emphasis should be given in investigating long term (at least 10 years) cognitive and neuropsychiatric deficits, as well as the later progression into brain diseases after $\mathrm{TBI}$ in future studies. Moreover, future retrospective studies on the influence of childhood or young age TBI on the mental health during old age, may shed light on the prevalence of TBI-related mental impairments in Malaysia, which in turn will propagate and mould TBI intervention studies to prevent these secondary outcomes of TBI.

Marching forward, TBI research in Malaysia should also cautiously and statistically account the factors that may influence their research hypotheses on TBI. Factors such as age and gender have been reported to significantly affect TBI outcome (Biswas et al., 2017; Ma et al., 2019; Marquez de la Plata et al., 2008; Munivenkatappa et al., $\underline{2016)}$. Some studies have suggested that those 50 years and above (Biswas et al., 2017; Marquez de la Plata et al., 2008) and children (Sariaslan et al., 2016) were at higher risk for poorer prognosis post TBI and were more vulnerable to long term impairments, with TBI in children having been related to late development of functional outcomes and neurodegeneration (Sariaslan et al., 2016). Gender-wise, while males have reported a higher TBI incidences, females have reported a higher fatality rate and poorer TBI prognosis, based on GCS scores, in some studies (Biswas et al., 2017; Kraus et al., 2000; Munivenkatappa et al., 2016; Wright et al., 2014), despite studies suggesting the neuroprotective effects of female hormones against TBI secondary outcomes (Deutsch et al., 2013; Ma et al., 2019). Despite these findings, majority of the Malaysian TBI population studies had not taken age (33 articles) or gender (36 articles) differences into statistical account. Among those that did account for age and gender in their results, only age was shown to have significantly affect and negatively correlate with the prognosis and functional outcome in TBI patients, while gender differences were mostly insignificant. The latter could be a result of the small sample size and gender disproportioned recruitment/participation of TBI patients in the studies.

Another factor that may affect TBI measures, which strongly applies to a multiracial country like Malaysia, is 
ethnicity. Differences in ethnicities in the Malaysian population may create a great heterogeneity effect in the sample, and therefore may potentially affect the TBI outcome and diagnosis. Ethnicity disparities have been suggested to influence TBI outcomes in western populations (Arango-Lasprilla \& Kreutzer, 2010; Brenner et al., 2020; Sorani et al., 2009; Staudenmayer et al., 2007), thus may be translated in Malaysia (Ali et al., 2013; Jeng et al., 2008) as well. Genetic diversity and cultural environment differences such as in food, beliefs and lifestyle between the ethnicities, may impact the recovery process post-injury and its functional outcomes (Lequerica \& Krch, 2014; Saltapidas \& Ponsford, 2008). The study by Saltapidas and Ponsford (2008) showed that culturally diverse populations exhibited varied understanding of $\mathrm{TBI}$, diverse negative emotions and even scored differently in post-injury outcome measurements, and therefore urged health professionals to understand the differences in beliefs among ethnicities that may impact TBI diagnosis and prognosis (Saltapidas \& Ponsford, 2008). However, like gender, ethnical differences as a confounder was hardly investigated or mentioned in the Malaysian population studies. Only five studies have acknowledged the ethnicity differences in the sample population (Abdullah et al., 2018; Ali et al., 2013; Jeng et al., 2008; Liew et al., 2009; Sharifuddin et al., 2012), with only one of them statistically proving the significant affect race had on brain injury (Jeng et al., 2008). Interestingly, the study by Ali et al (2013), showed that one of their cognitive tests, the Rey Auditory Verbal Learning Test (RAVLT) was significantly affected by ethnicity (Ali et al., 2013), regardless of $T B I$ and urged future $T B I$ research to account ethnicity differences in their cognitive results.

Taken together, the lack of statistical application and accounting of these factors (age, gender and ethnicity) and possibly others such as time since injury and education, may have stunted Malaysian TBI studies. This is because these factors may affect the pharmacokinetics and pharmacodynamics of treatments (Mangoni \& Jackson, 2004; Shah \& Gaedigk, 2018; Soldin \& Mattison, 2009). Therefore, future TBI studies in Malaysia should account for these factors in order to develop effective precision-based prescriptions to TBI patients, especially since genotype differences between ethnicities may influence treatment strategies. Besides that, future Malaysian TBI studies may also benefit from conducting nationwide TBI sampling and pooling of resources and data across states, which may translate better to the actual TBI population similar to the nationwide PDRM motor vehicle accident reports (PDRM, 2020a).
The lack of preclinical studies in Malaysia should also be of concern, as basic research may provide a more in depth understanding on the pathophysiology of TBI and the pharmacological aspects of interventions, that may manipulate the pathways of $\mathrm{TBI}$ and its secondary outcomes. Moreover, basic animal research may help hasten the investigations on factors, especially age and time since injury, influencing $T B I$, unlike population studies which requires years to see its effects.

Therefore, more time, effort, collaboration and funding should be placed into TBI research in Malaysia as a whole, in order to curb these issues and solve the annual ongoing problem of TBI cases and their future secondary outcomes, for the benefit of Malaysian road users and other TBI patients.

\subsection{CONCLUSIONS}

Traumatic brain injury is a devastating disorder that can affect anyone in the world. While the mortality rate reported in Malaysia was low, which may be underreported, it still may significantly impact the nation, both economically and socially, especially when considering the development of long-term outcomes and mental disorders after physical recovery. Despite this concern, TBI research in Malaysia was still found to be in its infancy, especially in the basic research area. Lack of TBI awareness in the population and unrectified limitations in TBI research in Malaysia, may result in devastating outcomes in the future for the Malaysian population and its economy. Given the yearly rise in TBI cases in Malaysia, more funds and support should be allocated into the TBI field, as there is a dire need for more effective TBI reporting systems as well as basic, translation and clinical research to be carried out in Malaysia, for the betterment of its people.

Supplementary Materials: Table S1: EPHPP tool, Table S2: AXIS tool, Table S3: CASP tool, Table S4: Cochrane RoB 2 tool, and Table S5: SYRCLE tool, are available online at https://neuroscirn.org/ojs/index.php/nrnotes/article/view/5 2 .

Acknowledgements: The authors declare that there was no grant received from any funding agency in the public, commercial or not-for-profit sectors.

Author Contributions: A.A. conceptualized the idea, performed the literature search, drafted and revised the paper. M.F.S. supervised and revised the paper. Both authors gave their final approval for the submission of this paper.

Conflicts of Interest: The authors declare no conflict of interest. 


\section{References}

Abdul Rahman, R. A., Hanapiah, F. A., Nikmat, A. W., Ismail, N. A., \& Manaf, H. (2019). Postural sway changes during static standing with concurrent task in children with traumatic brain injury. Neurosciences, 24(1), 29-35. https://doi.org/10.17712/nsj.2019.1.20180195

Abdul Rahman, R. A., Rafi, F., Hanapiah, F. A., Nikmat, A. W., Ismail, N. A., \& Manaf, H. (2018). Effect of Dual-Task Conditions on Gait Performance during Timed Up and Go Test in Children with Traumatic Brain Injury. Rehabilitation Research and Practice, 2018. https://doi.org/10.1155/2018/2071726

Abdullah, J. M., Kumaraswamy, N., Awang, N., Ghazali, M. M., \& Abdullah, M. R. (2005). Persistence of cognitive deficits following paediatric head injury without professional rehabilitation in rural East Coast Malaysia. Asian Journal of Surgery, 28(3), 163-167. https://doi.org/10.1016/S1015-9584(09)60334-1

Abdullah, M. F. I. L. B., Ng, Y. P., \& Sidi, H. B. (2018). Depression and anxiety among traumatic brain injury patients in Malaysia. Asian Journal of Psychiatry, 37, 67-70. https://doi.org/10.1016/i.aip.2018.08.017

Abdullah, M. F. I. L. B., Sidi, H., \& Ng, Y. P. (2019). Validation of the Malay version of the hospital anxiety and depression scale among patients with traumatic brain injury. International Medical Journal Malaysia, 18(2), 3-12.

https://www.scopus.com/inward/record.uri?eid=2-s2.085072749512\&partnerID=40\&md5=ab8345e3b4ad035ad2767ffc09facc85

Abdullah, M. I., Ahmad, A., Syed Saadun Tarek Wafa, S. W. W., Abdul Latif, A. Z., Mohd Yusoff, N. A., Jasmiad, M. K., Udin, N., \& Abdul Karim, K. (2020). Determination of calorie and protein intake among acute and sub-acute traumatic brain injury patients. Chinese Journal of Traumatology, In press. https://doi.org/10.1016/j.cjtee.2020.04.004

Ahmedy, F., Mazlan, M., Danaee, M., \& Abu Bakar, M. Z. (2020). Post-traumatic brain injury olfactory dysfunction: factors influencing quality of life. European Archives of Oto-Rhino-Laryngology, 277(5), 1343-1351. https://doi.org/10.1007/s00405-020-05823-0

Alanazi, H. O., Abdullah, A. H., Qureshi, K. N., \& Ismail, A. S. (2018). Accurate and dynamic predictive model for better prediction in medicine and healthcare. Irish Journal of Medical Science, 187(2), 501-513. https://doi.org/10.1007/s11845-017-1655-3

Ali, R., Wahab, S., Hamid, A., \& Rahman, A. (2013). Neuropsychological profile at three months post injury in patients with traumatic brain injury. Sains Malaysiana, 42(3), 403-408. https://www.scopus.com/inward/record.uri?eid=2-s2.084874136124\&partnerID=40\&md5=8d29aa49d5f6ac84928cbcb0bc34d254

Anada, R. P., Wong, K. T., Jayapalan, J. J., Hashim, O. H., \& Ganesan, D. (2018). Panel of serum protein biomarkers to grade the severity of traumatic brain injury. Electrophoresis, 39(18), 2308-2315. https://doi.org/10.1002/elps.201700407

Arango-Lasprilla, J. C., \& Kreutzer, J. S. (2010). Racial and ethnic disparities in functional, psychosocial, and neurobehavioral outcomes after brain injury. Journal of Head Trauma Rehabilitation, 25(2), 128-136. https://doi.org/10.1097/HTR.0b013e3181d36ca3

Asha'Ari, Z. A., Ahmad, R., Rahman, J., Kamarudin, N., \& Wan Ishlah, L. (2011). Contrecoup injury in patients with traumatic temporal bone fracture. Journal of Laryngology and Otology, 125(8), 781-785. https://doi.org/10.1017/S0022215111000545

Balakrishnan, B., Rus, R. M., Chan, K. H., Martin, A. G., \& Awang, M. S. (2019). Prevalence of Postconcussion Syndrome after Mild Traumatic Brain Injury in Young Adults from a Single Neurosurgical Center in East Coast of Malaysia. Asian Journal of Neurosurgery, 14(1), 201-205. https://doi.org/10.4103/ajns.AJNS 4918

Biswas, R. K., Kabir, E., \& King, R. (2017). Effect of sex and age on traumatic brain injury: a geographical comparative study. Archives of Public Health, 75, 43-43. https://doi.org/10.1186/s13690-017-0211-y

Brenner, E. K., Grossner, E. C., Johnson, B. N., Bernier, R. A., Soto, J., \& Hillary, F. G. (2020). Race and ethnicity considerations in traumatic brain injury research: Incidence, reporting, and outcome. Brain Injury, 34(6), 801-810. https://doi.org/10.1080/02699052.2020.1741033

CASP. (2018). CASP Case Control Study Checklist. https://casp-uk.net/casp-tools-checklists/

Centers for Disease Control and Prevention. (2019). Surveillance Report of Traumatic Brain Injury-related Emergency Department Visits, Hospitalizations, and Deaths-United States, 2014.

Chan, K. H., Tharakan, J., Pal, H. K., Khan, N., \& Tan, Y. C. (2010). Risk Factors and Phenytoin Prophylaxis for Early PostTraumatic Seizures among Patients with Traumatic Brain Injury. The Malaysian Journal of Medical Sciences, 17(4), 36-43. http://search.ebscohost.com/login.aspx?direct=true\&db=cmedm\&AN=22135559\&site=ehost-live

Chen, H., Richard, M., Sandler, D. P., Umbach, D. M., \& Kamel, F. (2007). Head injury and amyotrophic lateral sclerosis. American Journal of Epidemiology, 166(7), 810-816. https://doi.org/10.1093/aje/kwm153

Coronado, V. G., McGuire, L. C., Sarmiento, K., Bell, J., Lionbarger, M. R., Jones, C. D., Geller, A. I., Khoury, N., \& Xu, L. (2012). Trends in Traumatic Brain Injury in the U.S. and the public health response: 1995-2009. Journal of Safety Research, 43(4), 299-307. https://doi.org/10.1016/j.jsr.2012.08.011

Deutsch, E. R., Espinoza, T. R., Atif, F., Woodall, E., Kaylor, J., \& Wright, D. W. (2013). Progesterone's role in neuroprotection, a review of the evidence. Brain Research, 1530, 82-105. https://doi.org/https://doi.org/10.1016/j.brainres.2013.07.014 
Dewan, M. C., Rattani, A., Gupta, S., Baticulon, R. E., Hung, Y. C., Punchak, M., Agrawal, A., Adeleye, A. O., Shrime, M. G., Rubiano, A. M., Rosenfeld, J. V., \& Park, K. B. (2018). Estimating the global incidence of traumatic brain injury. Journal of Neurosurgery, 1-18. https://doi.org/10.3171/2017.10.jns17352

Downes, M. J., Brennan, M. L., Williams, H. C., \& Dean, R. S. (2016). Development of a critical appraisal tool to assess the quality of cross-sectional studies (AXIS). BMJ Open, 6(12), e011458. https://doi.org/10.1136/bmjopen-2016-011458

Fann, J. R., Hart, T., \& Schomer, K. G. (2009). Treatment for depression after traumatic brain injury: a systematic review. Journal of Neurotrauma, 26(12), 2383-2402. https://doi.org/10.1089/neu.2009.1091

Fleminger, S., Oliver, D. L., Lovestone, S., Rabe-Hesketh, S., \& Giora, A. (2003). Head injury as a risk factor for Alzheimer's disease: the evidence 10 years on; a partial replication. Journal of Neurology, Neurosurgery and Psychiatry, 74(7), 857862. https://doi.org/10.1136/innp.74.7.857

Gardner, R. C., Burke, J. F., Nettiksimmons, J., Goldman, S., Tanner, C. M., \& Yaffe, K. (2015). Traumatic brain injury in later life increases risk for Parkinson disease. Annals of Neurology, 77(6), 987-995. https://doi.org/10.1002/ana.24396

Hafiz, M. Z. M., \& Saffari, M. H. M. (2011). Characteristic differences in neuroimaging and physical findings between nonaccidental and accidental traumatic brain injury in young children. A local experience in general hospital of Kuala Lumpur. Medical Journal of Malaysia, 66(2), 95-100. http://search.ebscohost.com/login.aspx?direct=true\&db=cmedm\&AN=22106685\&site=ehost-live

Hamzah, N., Mohamad, N. A., Thiruselvam, I., Hariri, F., Veeramuthu, V., Mazlan, M., Narayanan, V., \& Ramli, N. (2019). Validity and reliability of the Neuropsychological Assessment Battery-Screening Module (S-NAB) in a subset of Malaysian population with mild traumatic brain injury (mTBI). Applied Neuropsychology: Adult, 1-11. https://doi.org/10.1080/23279095.2019.1648264

Haron, R. H., Musa, K. I., \& Haspani, M. S. M. (2011). An observational study of blood glucose levels during admission and 24 hours post-operation in a sample of patients with traumatic injury in a hospital in Kuala Lumpur. Malaysian Journal of Medical Sciences, 18(4), 68-76. http://www.embase.com/search/results?subaction=viewrecord\&from=export\&id=L362700286

Hassan, M. H., Hassan, W. M. N. W., Zaini, R. H. M., Shukeri, W. F. W. M., Abidin, H. Z., \& Eu, C. S. (2017). Balanced Fluid Versus Saline-Based Fluid in Post-operative Severe Traumatic Brain Injury Patients: Acid-Base and Electrolytes Assessment. Malaysian Journal of Medical Sciences, 24(5), 83-93. https://doi.org/10.21315/mjms2017.24.5.9

Hassan, W. M. N. W., Nasir, Y. M., Zaini, R. H. M., \& Shukeri, W. F. W. M. (2017). Target-controlled Infusion Propofol Versus Sevoflurane Anaesthesia for Emergency Traumatic Brain Surgery: Comparison of the Outcomes. Malaysian Journal of Medical Sciences, 24(5), 73-82. https://doi.org/10.21315/mims2017.24.5.8

Higgins, J. P., Altman, D. G., Gøtzsche, P. C., Jüni, P., Moher, D., Oxman, A. D., Savovic, J., Schulz, K. F., Weeks, L., \& Sterne, J. A. (2011). The Cochrane Collaboration's tool for assessing risk of bias in randomised trials. British Medical Journal, 343, d5928. https://doi.org/10.1136/bmj.d5928

Hooijmans, C. R., Rovers, M. M., de Vries, R. B. M., Leenaars, M., Ritskes-Hoitinga, M., \& Langendam, M. W. (2014). SYRCLE's risk of bias tool for animal studies. BMC Medical Research Methodology, 14, 43-43. https://doi.org/10.1186/1471-2288$\underline{14-43}$

Hyder, A. A., Wunderlich, C. A., Puvanachandra, P., Gururaj, G., \& Kobusingye, O. C. (2007). The impact of traumatic brain injuries: a global perspective. NeuroRehabilitation, 22(5), 341-353.

Ibrahim, M. I., Abdullah, M., Naing, L., Abdullah, J. M., Idris, Z., \& Aljunid, S. M. (2007). Cost effectiveness analysis of using multiple neuromodalities in treating severe traumatic brain injury in a developing country like Malaysia. Asian Journal of Surgery, 30(4), 261-266. https://doi.org/10.1016/S1015-9584(08)60036-6

Idris, Z., Ghani, R. I., Musa, K. I., Ibrahim, M. I., Abdullah, M., Nyi, N. N., \& Abdullah, J. M. (2007). Prognostic study of using different monitoring modalities in treating severe traumatic brain injury. Asian Journal of Surgery, 30(3), $200-208$. https://doi.org/10.1016/S1015-9584(08)60023-8

Idris, Z., Zenian, M. S., Muzaimi, M., \& Hamid, W. Z. W. A. (2014). Better Glasgow outcome score, cerebral perfusion pressure and focal brain oxygenation in severely traumatized brain following direct regional brain hypothermia therapy: $A$ prospective randomized study. Asian Journal of Neurosurgery, 9(3), 115-123. https://doi.org/10.4103/1793-5482.142690

Isa, R., Wan Adnan, W. A., Ghazali, G., Idris, Z., Ghani, A. R., Sayuthi, S., Awang, M. S., Ghazali, M. M., Naing, N. N., \& Abdullah, J. M. (2003). Outcome of severe traumatic brain injury: comparison of three monitoring approaches. Neurosurgical Focus, 15(6), E1. http://www.embase.com/search/results?subaction=viewrecord\&from=export\&id=L39712312

Jamaluddin, S., Wahab, M., Wahab, M., Ming, Y., \& Saiboon, I. (2011). National Trauma Database January 2009 to December 2009 - Fourth Report. http://www.acrm.org.my/ntrd/

Jeng, T. C., Haspani, M. S. M., Adnan, J. S., \& Naing, N. N. (2008). Delayed traumatic intracranial haemorrhage and progressive traumatic brain injury in a major referral centre based in developing country. Malaysian Journal of Medical Sciences, 15(4), 56-57. http://www.embase.com/search/results?subaction=viewrecord\&from=export\&id=L355356958 
Kan, C. H., Saffari, M., \& Khoo, T. H. (2009). Prognostic factors of severe traumatic brain injury outcome in children aged 2-16 years at a major Neurosurgical Referral Centre. Malaysian Journal of Medical Sciences, 16(4), 25-33. http://www.embase.com/search/results?subaction=viewrecord\&from=export\&id=L358181406

Kandasamy, R., Kanti Pal, H., Swamy, M., \& Abdullah, J. (2013). Cerebrospinal fluid nitric oxide metabolite levels as a biomarker in severe traumatic brain injury. International Journal of Neuroscience, 123(6), 385-391. https://doi.org/10.3109/00207454.2012.761983

Khalin, I., Alyautdin, R., Wong, T. W., Gnanou, J., Kocherga, G., \& Kreuter, J. (2016). Brain-derived neurotrophic factor delivered to the brain using poly (lactide-co-glycolide) nanoparticles improves neurological and cognitive outcome in mice with traumatic brain injury. Drug Delivery, 23(9), 3520-3528. https://doi.org/10.1080/10717544.2016.1199609

Khalin, I., Jamari, N. L. A., Razak, N. A., Bt Hasain, Z., Nor, M. A. M., Zainudin, M. H. A., Bt Omar, A., \& Alyautdin, R. (2016). A mouse model of weight-drop closed head injury: Emphasis on cognitive and neurological deficiency. Neural Regeneration Research, 11(4), 630-635. https://doi.org/10.4103/1673-5374.180749

Kiflie, A., Alias, N. A., Abdul Kareem, M. M., Mar, W., Abdullah, J. M., \& Naing, N. N. (2006). The prognostic value of early follow-up computerized tomography of the brain in adult traumatic brain injury. Medical Journal of Malaysia, 61(4), 466473. http://www.embase.com/search/results?subaction=viewrecord\&from=export\&id=L46271853

Kozlowski, D. A., Leasure, J. L., \& Schallert, T. (2013). The control of movement following traumatic brain injury. Comprehensive Physiology, 3(1), 121-139. https://doi.org/10.1002/cphy.c110005

Kraus, J. F., Peek-Asa, C., \& McArthur, D. (2000). The independent effect of gender on outcomes following traumatic brain injury: a preliminary investigation. Neurosurgical Focus, 8(1), e5. https://doi.org/10.3171/foc.2000.8.1.156

Kumaraswamy, N., Naziah, A., Abdullah, J., Ariff, A., Abdullah, M. R., \& Ghazaime, G. (2002). Outcome of children with traumatic brain injury in rural Malaysia. Journal of Clinical Neuroscience, 9(3), 251-255. https://doi.org/10.1054/jocn.2001.1047

Lai, C. Q., Ibrahim, H., Abd Hamid, A. I., Abdullah, M. Z., Azman, A., \& Abdullah, J. M. (2020). Detection of Moderate Traumatic Brain Injury from Resting-State Eye-Closed Electroencephalography. Computational Intelligence and Neuroscience, 2020, 8923906. https://doi.org/10.1155/2020/8923906

Leong, B. K., Mazlan, M., Abd Rahim, R. B., \& Ganesan, D. (2013). Concomitant injuries and its influence on functional outcome after traumatic brain injury. Disability and Rehabilitation, 35(18), 1546-1551. http://www.embase.com/search/results?subaction=viewrecord\&from=export\&id=L563071183

Lequerica, A., \& Krch, D. (2014). Issues of cultural diversity in acquired brain injury (ABI) rehabilitation. NeuroRehabilitation, 34(4), 645-653. https://doi.org/10.3233/nre-141079

Liew, B. S., Johari, S. A., Nasser, A. W., \& Abdullah, J. (2009). Severe traumatic brain injury: Outcome in patients with diffuse axonal injury managed conservatively in Hospital Sultanah Aminah, Johor Bahru - An observational study. Medical Journal of Malaysia, 64(4), 280-288. http://www.embase.com/search/results?subaction=viewrecord\&from=export\&id=L359782457

Lucke-Wold, B. P., Nguyen, L., Turner, R. C., Logsdon, A. F., Chen, Y.-W., Smith, K. E., Huber, J. D., Matsumoto, R., Rosen, C. L., Tucker, E. S., \& Richter, E. (2015). Traumatic brain injury and epilepsy: Underlying mechanisms leading to seizure. Seizure, 33, 13-23. https://doi.org/https://doi.org/10.1016/j.seizure.2015.10.002

Ludin, S. M., Rashid, N. A., Awang, M. S., \& Nor, M. B. M. (2019). Functional Outcomes 6 Months After Severe Traumatic Brain Injury Following Admission Into Intensive Care Unit: A Cohort Study in Two Tertiary Hospitals. Clinical Nursing Research, 28(7), 830-851. https://doi.org/10.1177/1054773818767551

Ma, C., Wu, X., Shen, X., Yang, Y., Chen, Z., Sun, X., \& Wang, Z. (2019). Sex differences in traumatic brain injury: a multidimensional exploration in genes, hormones, cells, individuals, and society. Chinese Neurosurgical Journal, $5(1), 24$. https://doi.org/10.1186/s41016-019-0173-8

Malaysia Health Technology Assessment Section (MaHTAS). (2015). Early Management Of Head Injury In Adults. https://www.moh.gov.my/moh/resources/maklumat\%20terkini/DRAF\%20CPG/Draft CPG Early Management of Head Injury $23.11 .2015 . \mathrm{pdf}$

Mangoni, A. A., \& Jackson, S. H. D. (2004). Age-related changes in pharmacokinetics and pharmacodynamics: basic principles and practical applications. British Journal of Clinical Pharmacology, 57(1), 6-14. https://doi.org/10.1046/i.13652125.2003.02007.x

Marquez de la Plata, C. D., Hart, T., Hammond, F. M., Frol, A. B., Hudak, A., Harper, C. R., O'Neil-Pirozzi, T. M., Whyte, J., Carlile, M., \& Diaz-Arrastia, R. (2008). Impact of age on long-term recovery from traumatic brain injury. Archives of Physical Medicine and Rehabilitation, 89(5), 896-903. https://doi.org/10.1016/j.apmr.2007.12.030

Mazlan, M., Ghani, S. Z. S. A., Tan, K. F., \& Subramanian, P. (2016). Life satisfaction and strain among informal caregivers of patients with traumatic brain injury in Malaysia. Disability and rehabilitation, 38(22), 2198-2205. https://doi.org/10.3109/09638288.2015.1123307

McKee, A. C., \& Daneshvar, D. H. (2015). The neuropathology of traumatic brain injury. Handbook of Clinical Neurology, 127, 45-66. https://doi.org/10.1016/B978-0-444-52892-6.00004-0 
Moher, D., Shamseer, L., Clarke, M., Ghersi, D., Liberati, A., Petticrew, M., Shekelle, P., Stewart, L. A., \& Group, P.-P. (2015). Preferred reporting items for systematic review and meta-analysis protocols (PRISMA-P) 2015 statement. Systematic Reviews, 4(1), 1. https://doi.org/10.1186/2046-4053-4-1

Munivenkatappa, A., Agrawal, A., Shukla, D. P., Kumaraswamy, D., \& Devi, B. I. (2016). Traumatic brain injury: Does gender influence outcomes? International Journal of Critical IIIness and Injury Science, 6(2), 70-73. https://doi.org/10.4103/2229-5151.183024

Muthuraju, S., Islam, M. R., Pati, S., Jaafar, H., Abdullah, J. M., \& Yusoff, K. M. (2014). Normobaric hyperoxia treatment prevents early alteration in dopamine level in mice striatum after fluid percussion injury: A biochemical approach. International Journal of Neuroscience, 125(9), 686-692. https://doi.org/10.3109/00207454.2014.961065

Muthuraju, S., Pati, S., Rafiqul, M., Abdullah, J. M., \& Jaafar, H. (2012). IntelliCage provides voluntary exercise and an enriched environment, improving locomotive activity in mice following fluid percussion injury. Basal Ganglia, 2(3), 143151. https://doi.org/10.1016/i.baga.2012.06.004

Muthuraju, S., Pati, S., Rafiqul, M., Abdullah, J. M., \& Jaafar, H. (2013). Effect of normabaric hyperoxia treatment on neuronal damage following fluid percussion injury in the striatum of mice: A morphological approach. Journal of Biosciences, 38(1), 93-103. https://doi.org/10.1007/s12038-012-9290-7

Muthuraju, S., Taha, S., Pati, S., Rafique, M., Jaafar, H., \& Abdullah, J. M. (2013). Normabaric hyperoxia treatment improved locomotor activity of $\mathrm{C} 57 \mathrm{BL} / 6 \mathrm{~J}$ mice through enhancing dopamine genes following fluid-percussion injury in striatum. International Journal of Biomedical Science, 9(4), 194-204. http://www.embase.com/search/results?subaction=viewrecord\&from=export\&id=L372022611

Nandrajog, P., Idris, Z., Azlen, W. N., Liyana, A., \& Abdullah, J. M. (2017). The use of event-related potential (P300) and neuropsychological testing to evaluate cognitive impairment in mild traumatic brain injury patients. Asian Journal of Neurosurgery, 12(3), 447-453. https://doi.org/10.4103/1793-5482.180921

Narayanan, V., Veeramuthu, V., Ahmad-Annuar, A., Ramli, N., Waran, V., Chinna, K., Bondi, M. W., Delano-Wood, L., \& Ganesan, D. (2016). Missense mutation of Brain Derived Neurotrophic Factor (BDNF) alters neurocognitive performance in patients with mild traumatic brain injury: A longitudinal study. PLOS ONE, 11(7). https://doi.org/10.1371/journal.pone.0158838

Nemetz, P. N., Leibson, C., Naessens, J. M., Beard, M., Kokmen, E., Annegers, J. F., \& Kurland, L. T. (1999). Traumatic brain injury and time to onset of Alzheimer's disease: a population-based study. American Journal of Epidemiology, 149(1), 3240. https://doi.org/10.1093/oxfordjournals.aje.a009724

Nicholl, J., \& LaFrance, W. C., Jr. (2009). Neuropsychiatric sequelae of traumatic brain injury. Seminars in Neurology, 29(3), 247-255. https://doi.org/10.1055/s-0029-1223878

Norli, M. H. M., Al Zahari, M. A. F. H. M., Marwan, S. H., \& Abdullah, A. H. (2018). Computational analysis on skull fractures and brain injury using finite element analysis. International Journal of Engineering and Technology (UAE), 7(4), $119-122$. https://www.scopus.com/inward/record.uri?eid=2-s2.085056702905\&partnerID=40\&md5=30fe93729ed6fd68f63b809d5e186b1d

Pavlova, V., Filipova, E., Uzunova, K., Kalinov, K., \& Vekov, T. (2018). Pioglitazone Therapy and Fractures: Systematic Review and Meta- Analysis. Endocrine, metabolic \& Immune Disorders - Drug Targets, 18(5), 502-507. https://doi.org/10.2174/1871530318666180423121833

PDRM, R. M. P. (2020a). Jumlah Kemalangan Jalan Raya Mengikut Negeri Tahun 2003 -2019. http://www.data.gov.my/data/ms MY/dataset/jumlah-kemalangan-jalan-raya-mengikut-negeri

PDRM, R. M. P. (2020b). Jumlah Kematian Kemalangan Jalanraya Mengikut Tahun Dan Negeri Tahun 2003-2019. http://www.data.gov.my/data/ms MY/dataset/jumlah-kematian-disebabkan-kemalangan-jalan-raya-mengikut-tahundan-negeri

Pratap-Chand, R., Sinniah, M., \& Salem, F. A. (1988). Cognitive evoked potential (P300): a metric for cerebral concussion. Acta Neurologica Scandinavica, 78(3), 185-189. https://doi.org/10.1111/j.1600-0404.1988.tb03643.x

Project, E. P. H. P. (1998). Quality assessment tool for quantitative studies. Retrieved April from http://www.ephpp.ca/tools.html

Rabinowitz, A. R., \& Levin, H. S. (2014). Cognitive sequelae of traumatic brain injury. Psychiatric Clinics of North America, 37(1), 1-11. https://doi.org/10.1016/j.psc.2013.11.004

Rai, V. R. H., Phang, L. F., Sia, S. F., Amir, A., Veerakumaran, J. S., Kassim, M. K. A., Othman, R., Tah, P. C., Loh, P. S., Jailani, M. I. O., \& Ong, G. (2017). Effects of immunonutrition on biomarkers in traumatic brain injury patients in Malaysia: a prospective randomized controlled trial. BMC Anesthesiology, 17(1), 81. https://doi.org/10.1186/s12871-017-0369-4

Rajandram, R. K., Syed Omar, S. N., Rashdi, M. F., \& Abdul Jabar, M. N. (2014). Maxillofacial injuries and traumatic brain injury--a pilot study. Dental Traumatology, 30(2), 128-132. https://doi.org/10.1111/edt.12052

Rasheed, W., \& Tang, T. B. (2020). Anomaly detection of moderate traumatic brain injury using auto-regularized multiinstance one-class SVM. IEEE Transactions on Neural Systems and Rehabilitation Engineering, 28(1), 83-93.

https://doi.org/10.1109/TNSRE.2019.2948798 
Razak, A., Nordin, R., Abd Rahman, N., \& Ramli, R. (2017). A retrospective analysis of the relationship between facial injury and mild traumatic brain injury. Dental Traumatology, 33(5), 400-405. https://doi.org/10.1111/edt.12355

Rubiano, A. M., Carney, N., Chesnut, R., \& Puyana, J. C. (2015). Global neurotrauma research challenges and opportunities. Nature, 527(7578), S193-197. https://doi.org/10.1038/nature16035

Saltapidas, H., \& Ponsford, J. (2008). The influence of cultural background on experiences and beliefs about traumatic brain injury and their association with outcome. Brain Impairment, 9(1), 1-13. https://doi.org/10.1375/brim.9.1.1

Sariaslan, A., Sharp, D. J., D'Onofrio, B. M., Larsson, H., \& Fazel, S. (2016). Long-term outcomes associated with traumatic brain injury in childhood and adolescence: a nationwide swedish cohort study of a wide range of medical and social outcomes. PLoS Medicine, 13(8), e1002103. https://doi.org/10.1371/journal.pmed.1002103

Sethi, D., Aljunid, S., Saperi, S. B., Zwi, A. B., Hamid, H., Mustafa, A. N., \& Abdullah, A. H. (2002). Comparison of the effectiveness of major trauma services provided by tertiary and secondary hospitals in Malaysia. Journal of Trauma, 53(3), 508-516. https://doi.org/10.1097/00005373-200209000-00019

Shadli, R. M., Pieter, M. S., Yaacob, M. J., \& Rashid, F. A. (2011). APOE genotype and neuropsychological outcome in mild-tomoderate traumatic brain injury: A pilot study. Brain Injury, 25(6), 596-603. https://doi.org/10.3109/02699052.2011.572947

Shah, R. R., \& Gaedigk, A. (2018). Precision medicine: does ethnicity information complement genotype-based prescribing decisions? Therapeutic Advances in Drug Safety, 9(1), 45-62. https://doi.org/10.1177/2042098617743393

Sharda, P., Haspani, S., \& Idris, Z. (2014). Factors prognosticating the outcome of decompressive craniectomy in severe traumatic brain injury: A Malaysian experience. Asian Journal of Neurosurgery, 9(4), 203-212. https://doi.org/10.4103/1793-5482.146605

Sharifuddin, A., Adnan, J., Ghani, A. R., \& Abdullah, J. M. (2012). The role of repeat head computed tomography in the management of mild traumatic brain injury patients with a positive initial head CT. Medical Journal of Malaysia, 67(3), 305-308. http://www.embase.com/search/results?subaction=viewrecord\&from=export\&id=L365351322

Soldin, O. P., \& Mattison, D. R. (2009). Sex differences in pharmacokinetics and pharmacodynamics. Clinical Pharmacokinetics, 48(3), 143-157. https://doi.org/10.2165/00003088-200948030-00001

Song, C. H., Ahmad, M. Z., Hamid, S. A. A., \& Adnan, W. N. A. W. (2019). Association of non-isolated vomiting with traumatic brain injury in children with minor head trauma. Pakistan Paediatric Journal, 43(2), 87-92. http://www.embase.com/search/results?subaction=viewrecord\&from=export\&id=L2002341690

Song, C. H., Ahmad, M. Z., Siti-Azrin, A. H., \& Wan-Nor-Asyikeen, W. A. (2019). The identification of key factors predictive of traumatic brain injury in paediatric patients with a minor blunt head injury. Hong Kong Journal of Emergency Medicine, In press. https://doi.org/10.1177/1024907919836568

Sorani, M. D., Lee, M., Kim, H., Meeker, M., \& Manley, G. T. (2009). Racelethnicity and outcome after traumatic brain injury at a single, diverse center. Journal of Trauma, 67(1), 75-80. https://doi.org/10.1097/TA.0b013e31818234e8

Staudenmayer, K. L., Diaz-Arrastia, R., de Oliveira, A., Gentilello, L. M., \& Shafi, S. (2007). Ethnic disparities in long-term functional outcomes after traumatic brain injury. Journal of Trauma, 63(6), 1364-1369. https://doi.org/10.1097/TA.0b013e31815b897b

Taha, Z., Arif Hassan, M., \& Hasanuddin, I. (2015). Analytical modelling of soccer heading. Sadhana-Academy Proceedings in Engineering Sciences, 40(5), 1567-1578. https://doi.org/10.1007/s12046-015-0383-5

Tay, E. L., Lee, S. W. H., Jamaluddin, S. F., Tam, C. L., \& Wong, C. P. (2016). The epidemiology of childhood brain injury in the state of Selangor and Federal Territory of Kuala Lumpur, Malaysia. BMC Pediatrics, 16(1). https://doi.org/10.1186/s12887-016-0590-1

Tropeano, M. P., Spaggiari, R., lleyassoff, H., Park, K. B., Kolias, A. G., Hutchinson, P. J., \& Servadei, F. (2019). A comparison of publication to TBI burden ratio of low- and middle-income countries versus high-income countries: how can we improve worldwide care of TBI? Neurosurgical Focus, 47(5), E5. https://doi.org/10.3171/2019.8.Focus19507

Veeramuthu, V., Hariri, F., Narayanan, V., Tan, L. K., Ramli, N., \& Ganesan, D. (2016). Microstructural change and cognitive alteration in maxillofacial trauma and mild traumatic brain injury: A diffusion tensor imaging study. Journal of Oral and Maxillofacial Surgery, 74(6), 1197.e1-1197.e10. https://doi.org/10.1016/j.joms.2016.01.042

Veeramuthu, V., Narayanan, V., Kuo, T. L., Delano-Wood, L., Chinna, K., Bondi, M. W., Waran, V., Ganesan, D., \& Ramli, N. (2015). Diffusion tensor imaging parameters in mild traumatic brain injury and its correlation with early neuropsychological impairment: A longitudinal study. Journal of Neurotrauma, 32(19), 1497-1509. https://doi.org/10.1089/neu.2014.3750

Veeramuthu, V., Narayanan, V., Ramli, N., Hernowo, A., Waran, V., Bondi, M. W., Delano-Wood, L., \& Ganesan, D. (2017). Neuropsychological Outcomes in Patients with Complicated Versus Uncomplicated Mild Traumatic Brain Injury: 6-Month Follow-Up. World Neurosurgery, 97, 416-423. https://doi.org/10.1016/i.wneu.2016.10.041

Veeramuthu, V., Pancharatnam, D., Poovindran, A. R., Musthapha, N. A., Thong, W. K., Mazlan, M., Waran, V., \& Ganesan, D. (2014). Cognitive impairments in mild traumatic brain injury and genetic polymorphism of apolipoprotein E: A preliminary study in a level i trauma center. Neurology Asia, 19(1), 69-77. http://www.embase.com/search/results?subaction=viewrecord\&from=export\&id=L372767064 
Veeramuthu, V., Seow, P., Narayanan, V., Wong, J. H. D., Tan, L. K., Hernowo, A. T., \& Ramli, N. (2018). Neurometabolites Alteration in the Acute Phase of Mild Traumatic Brain Injury (mTBI): An in Vivo Proton Magnetic Resonance Spectroscopy (1H-MRS) Study. Academic Radiology, 25(9), 1167-1177. https://doi.org/10.1016/i.acra.2018.01.005

Vijian, K., Teo, E. G., Kanesen, D., \& Wong, A. S. H. (2020). Initial leucocytosis and other significant indicators of poor outcome in severe traumatic brain injury: An observational study. Chinese Neurosurgical Journal, 6(1), Article 5. https://doi.org/10.1186/s41016-020-0185-4

Wright, D. W., Espinoza, T. R., Merck, L. H., Ratcliff, J. J., Backster, A., \& Stein, D. G. (2014). Gender differences in neurological emergencies part II: a consensus summary and research agenda on traumatic brain injury. Academic Emergency Medicine, 21(12), 1414-1420. https://doi.org/10.1111/acem.12532

You, X., Liew, B. S., Rosman, A. K., Dcsn, Musa, K. I., \& Idris, Z. (2018). The estimated cost of surgically managed isolated traumatic head injury secondary to road traffic accidents. Neurosurgical Focus, 44(5), E7. https://doi.org/10.3171/2018.1.FOCUS17796 